\title{
Initial Building Investigations at Aberdeen Proving Ground, Maryland: Building E5375
}

Energy Systems Division Argonne National Laboratory

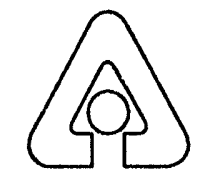

Operated by The University of Chicago, under Contract W-31-109-Eng-38, for the United States Department of Energy 


\section{Argonne National Laboratory}

Argonne National Laboratory, with facilities in the states of Illinois and Idaho, is owned by the United States Government, and operated by the University of Chicago under the provisions of a contract with the Department of Energy.

This technical memo is a product of Argonne's Energy Systems (ES)

Division. For information on the division's scientific and engineering activities, contact:

Director, Energy Systems Division

Argonne National Laboratory

Argonne, llinois 60439-4815

Telephone (708) 252-3724

Presented in this technical memo are preliminary results of ongoing work or work that is more limited in scope and depth than that dessribed in formal reports issued by the ES Division.

\section{Disclaimer}

This report was prepared as an account of work sponsored by an agency of the United States Government. Neither the United States Government nor any agency thereof, nor any of their employees, makes any warranty, express or implied, or assumes any legal liability or responsibility for the accuracy, completeness, or usefulness of any information, apparatus, product, or process disclosed, or represents that its use would not infringe privately owned rights. Reference herein to any specific commercial product, process, or service by trade name, trademark, manufacturer, or therwise, does not necessarily constitute or imply its endorsement, recommendation, or favoring by the United States Government or any agency thereof. The views and opinions of authors expressed herein do not necessarily state or reflect those of the United States Government or any agency thereof.

Available to DOE and DOE contractors from the Office of Scientific and Technical Information, P.O. Box 62, Oak Ridge, TN 37831; prices available from (615) 576-8401.

Available to the public from the National Technical Information Service, U.S. Department of Commerce, 5285 Port Royal Hoad, Springfield, VA 22161. 


\section{Initial Building Investigations at Aberdeen Proving Ground, Maryland: Building E5375}

by K.L. Brubaker, J.M. Dougherty, and C. Tome

Reclamation Engineering and Geosciences Section, Energy Systems Division, Argonne National Laboratory, 9700 South Cass Avenue, Argonne, lllinois 60439

June 1993

Work sponsored by United States Department of Defense, United States Army,

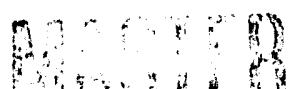
Aberdeen Proving Ground, Maryland 
This document is printed on recycled paper. 


\section{Contents}

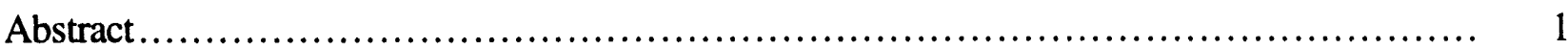

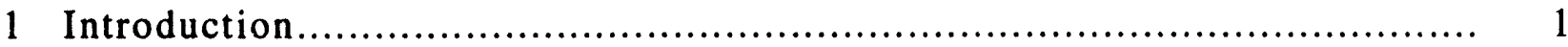

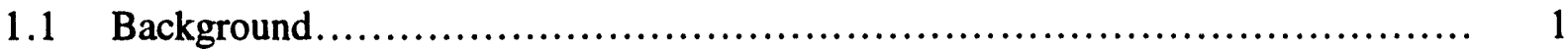

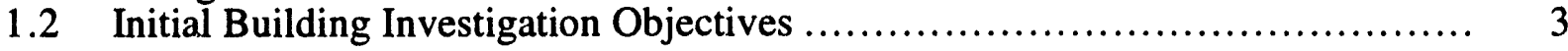

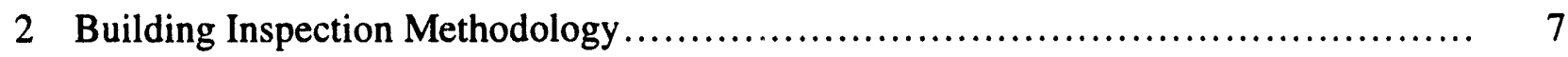

3 Summary of Historical Records Searcn for Building E5375 .................... 8

4 Description of Building E5375 ........................................... 9

4.1 Site Description ........................................................ 12

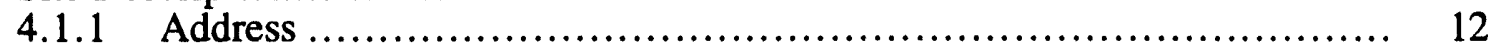

4.1.2 Proximity to Other Buildings......................................... 12

4.1.3 Exterior Footprint Dimensions...................................... 12

4.1.4 Surface Soils and Topographical Conditions......................... 13

4.1.5 Vegetation in the Immediate Vicinity .............................. 13

4.1.6 External Aboveground Structures or Equipment...................... 13

4.1.7 Connections with Adjacent Buildings............................... 13

4.1.8 Location and Type of Underground Structures........................ 14

4.1.9 Location and Type of Surface Drainage System...................... 14

4.1.10 Utility Access Points and Utility Type............................. 14

4.1.11 Piping Exiting the Building and Entering the Ground................... 14

4.1.12 Locatic $n$ and Direction of Nearby Roads and Sidewalks .............. 14

4.2 North Exterior Elevation.................................................... 14

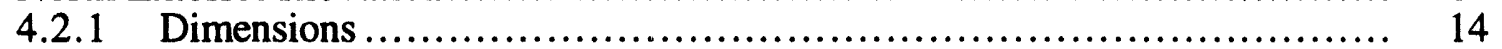

4.2.2 Material of Construction................................................. 16

4.2 .3 Doors and Windows .............................................. 16

4.2.4 Piping along or Connected with this Face of the Building ........... 16

4.2.5 Utility Connections ................................................... 16

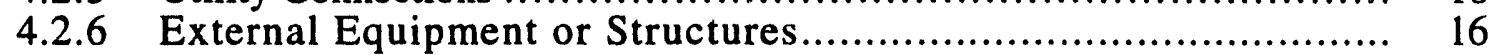

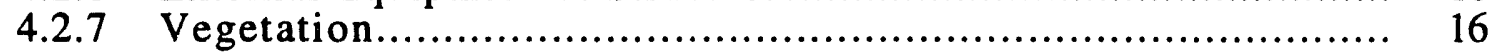

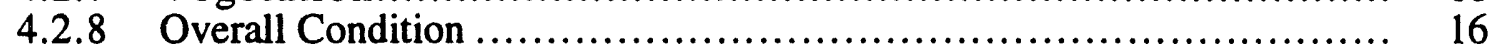

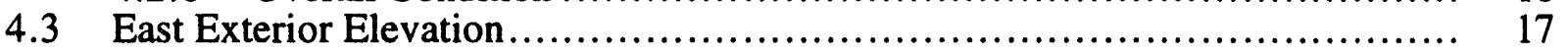

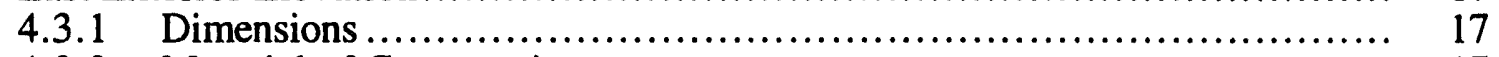

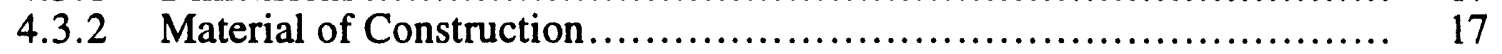

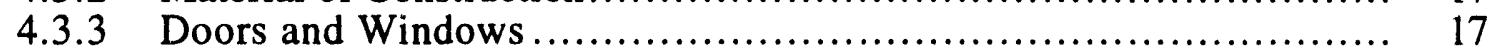

4.3.4 Piping along or Connected with this Face of the Building ................ 17

4.3.5 Utility Connections ............................................... 17

4.3.6 External Equipment or Structures.................................... 17

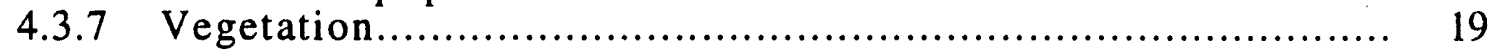

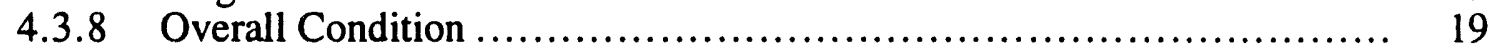

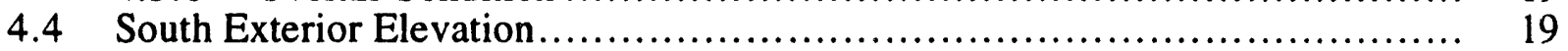

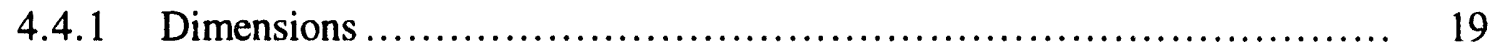

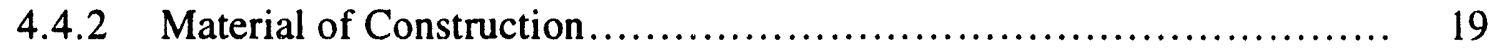

4.4.3 Doors and Windows ........................................... 19

4.4.4 Piping along or Connected with this Face of the Building ........... 19

4.4.5 Utility Connections ............................................ 21 


\section{Contents (Cont.)}

4.4.6 External Equipment or Structures........................................ 21

4.4.7 Vegetation.......................................................... 21

4.4.8 Overall Condition .................................................... 21

4.5 West Exterior Elevation ................................................. 21

4.5.1 Dimensions ..................................................... 21

4.5.2 Material of Construction............................................ 21

4.5.3 Doors and Windows .......................................... 23

4.5.4 Piping along or Connected with this Face of the Building ........... 23

4.5.5 Utility Connections ............................................. 23

4.5.6 External Equipment or Structures...................................... 23

4.5 .7 Vegetation....................................................... 23

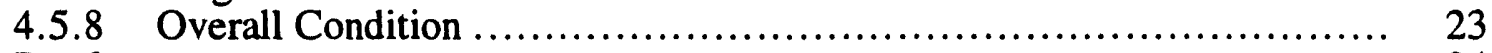

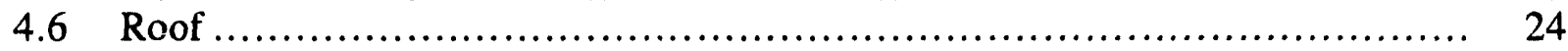

4.6.1 Type and Dimensions .............................................. 24

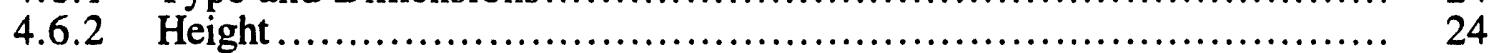

4.6.3 Surface Materials.................................................... 24

4.6.4 Structural Materials Used in the Roof Support System ............... 24

4.6 .5 Condition ............................................................. 24

4.6.6 Equipment Located at, on, or in the Roof ......................... 24

4.6.7 Chimneys, Roof Vents, or Vent Stacks .......................... 25

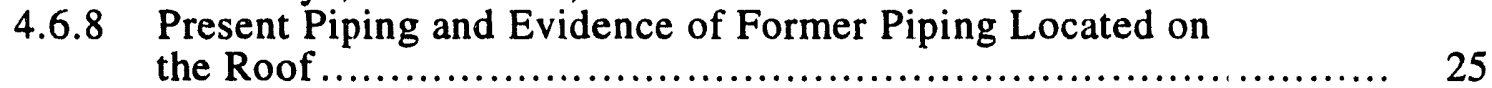

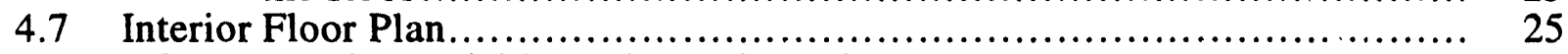

4.7.1 Number and Dimensions of Interior Rooms.......................... 25

4.7.2 Room Perimeter Walls ........................................ 25

4.7.3 Floor Construction Materials, Condition, and Configuration.............. 25

4.7.4 Floor Penetrations.................................................. 31

4.7.5 Location and Size of Interior Partitions.............................. 31

4.7.6 Equipment or Supplies Present ....................................... 31

4.8 North Interior Elevation........................................................ 32

4.8.1 Wall Characteristics............................................. 32

4.8.2 Interior-Wall Finish Materials................................................. 32

4.8.3 Piping Attached to or Associated with the Wall.................... 32

4.8.4 Equipment Connected with this Elevation .......................... 33

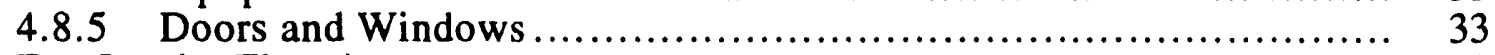

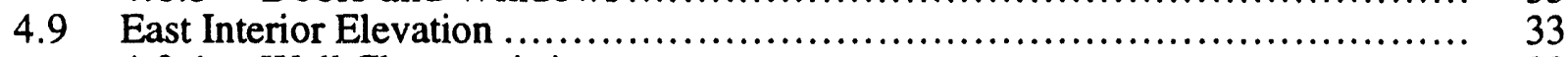

4.9.1 Wall Characteristics.......................................................

4.9.2 Interior-Wall Finish Materials........................................ 33

4.9.3 Piping Attached to or Associated with the Wall ...................... 33

4.9.4 Equipment Connected with this Elevation ........................... 33

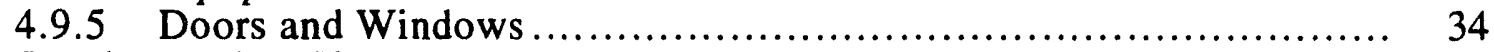

4.10 South Interior Elevation.............................................................. 34

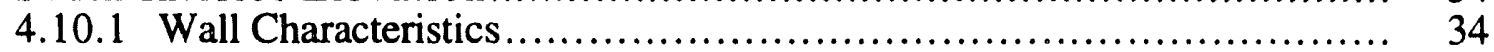

4.10.2 Interior-Wall Finish Materials.................................................. 34

4.10.3 Piping Attached to or Associated with the Wall..................... 34

4.10.4 Equipment Connected with this Elevation ........................... 34

4.10 .5 Doors and Windows ............................................ 34

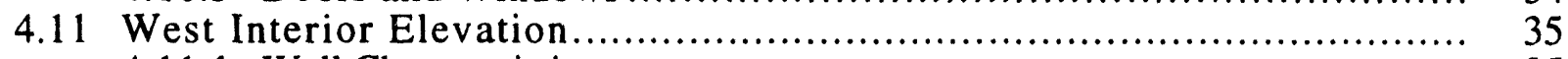

4.11.1 Wall Characteristics.................................................. 35

4.11.2 Interior-Wall Finish Materials......................................... 35 


\section{Contents (Cont.)}

4.11.3 Piping Attached to or Associated with the Wall ..................... 35

4.11.4 Equipment Connected with this Elevation ........................... 35

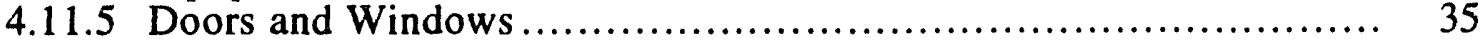

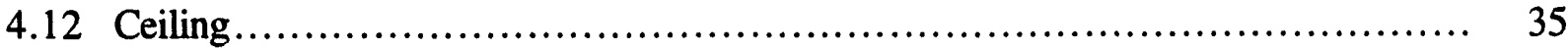

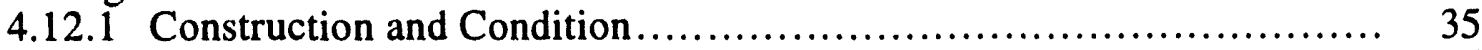

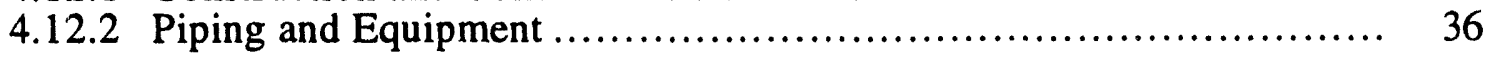

5 Summary of the Geophysics Investigation .................................. 37

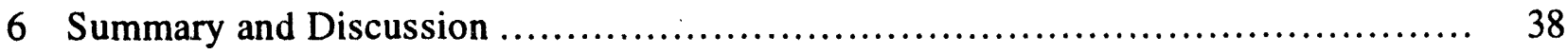

$6.1 \quad$ Building Operations ........................................................ 38

6.2 Summary of Potentially Contaminated Compartments ..................... 38

7 References .............................................................. 40

\section{Figures}

1 Map Showing the Location of Aberdeen Proving Ground ...................... 2

2 Decommissioning Process for Buildings at Aberdeen Proving Ground.............. 4

3 General Site Map of Aberdeen Proving Ground in the Vicinity of Building E5375 .............................................................. 10

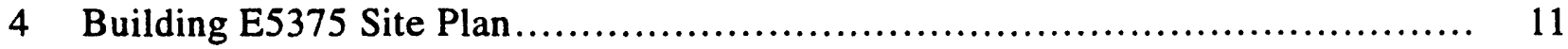

5 Building E5375 North Exterior Elevation.................................... 15

6 Building E5375 East Exterior Elevation........................................ 18

7 Building E5375 South Exterior Elevation...................................... 20

8 Building E5375 West Exterior Elevation...................................... 22

9 Building E5375 Floor Plan........................................... 26

10 Building E5375 North Interior Elevation ................................ 27

11 Building E5375 East Interior Elevation .................................... 28

12 Building E5375 South Interior Elevation ..................................... 29

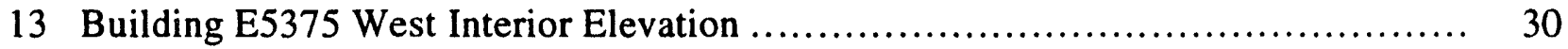




\title{
Initial Building Investigations at Aberdeen Proving Ground, Maryland: Building E5375
}

by

\author{
K.L. Brubaker, J.M. Dougherty, and C. Tome
}

\begin{abstract}
As part of a building decommissioning and demolition program at Aberdeen Proving Ground, a detailed inspection of each target building is being conducted in order to characterize and describe the state of the building as it currently exists and to identify areas potentially contaminated with toxic or other hazardous substances. Room surfaces, drains and sumps, remaining equipment, and such associated exterior aboveground and underground appurtenances as tanks and pipelines are among the features, generically termed compartments, that may be potentially contaminated. Detailed drawings are being prepared for each building to illustrate the existing structure. This report presents the results of the inspection of Building E5375 in the Edgewood/Canal Creek area of Aberdeen Proving Ground. Nine potentially contaminated compartments were identified in this building and its vicinity.
\end{abstract}

\section{Introduction}

\subsection{Background}

The U.S. Army Aberdeen Proving Ground (APG) is located on Chesapeake Bay in Harford and Baltimore Counties, Maryland, and occupies a total area of approximately 30,000 acres. Figure 1 shows the location of APG and its subdivision into the Edgewood and Aberdeen areas. The primary mission at APG is the testing and evaluation of U.S. Army materiel. Since its beginning in 1917, the Edgewood area of APG has been the principal location for chemical-warfare-agent research, development, and testing in the United States. APG was also the location of chemical-warfare-agent production facilities during the two world wars and has been a center for the storage of chemical-warfare materiel (Nemeth 1989).

Many buildings at APG constructed between 1917 and the 1950s are no longer used because of obsolescence and their poor state of repair. APG desires to decommission and demolish approximately 30 of these buildings at the present time. Because most of them were used 


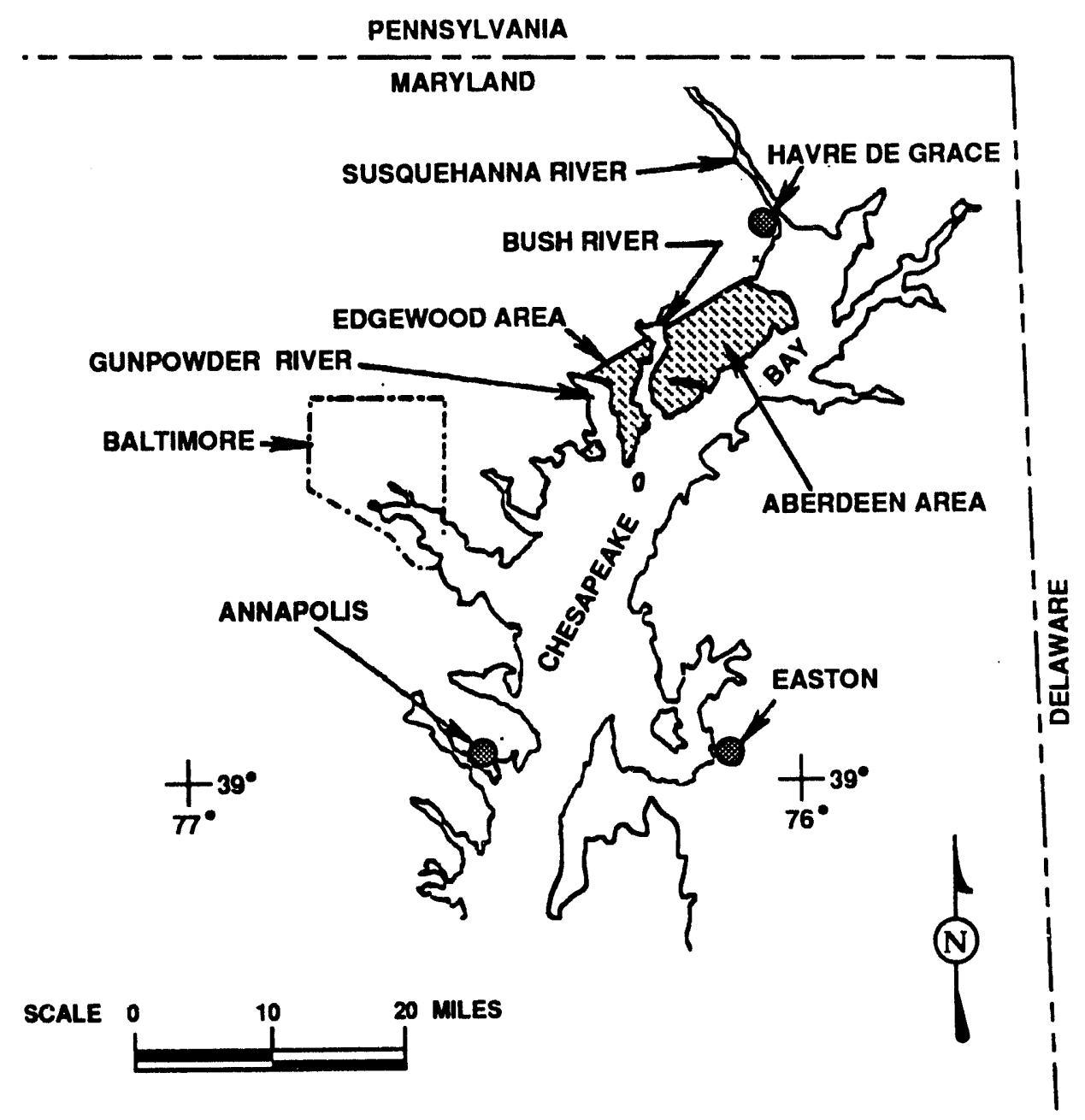

SHADED AREA INDICATES
ABERDEEN PROVING GROUND

FIGURE 1 Map Showing the Location of Aberdeen Proving Ground

for research, development, testing, and pilot-scale production testing of chemical-warfare agents and other military-unique substances, including incendiary materials and munitions containing these materials, the potential exists for parts of these buildings to be contaminated with these substances, their degradation products, and other laboratory or industrial chemicals. The buildings, together with their associated external structures or appurtenances, including underground or aboveground storage tanks, pipelines, and outbuildings, may contribute to existing environmental problems at APG. Uncontrolled release of toxic materials during building decommissioning and demolition may constitute an additional threat to human health and safety.

APG has commissioned Argonne National Laboratory (ANL) to carry out a program to address these concerns. Argonne's approach to the problem consists of a multiphase program of investigation for each individual building, which includes an initial building-evaluation phase, one or more sampling and analysis phases, and a final demolition-planning phase. A preliminary risk assessment for the demolition is prepared in phase one and updated as subsequent phases are 
executed. After the investigation is completed, a final building-demolition risk assessment is available for use in demolition planning and execution. Figure 2 shows this process in flowchart form.

This report presents the results from the initial inspection for Building E5375 that was conducted on May 5, 1992, by the ANL inspection team. Concurrently, a separate team of ANL geophysicists conducted a geophysical survey of the area surrounding Building E5375.

\subsection{Initial Building Investigation Objectives}

The principal objective of the initial investigation is to obtain the information necessary for the development of a field sampling plan for the building and for the development of the preliminary risk assessment. A secondary objective is to gather information about the structure that will be required in planning the eventual demolition or that may assist the Army in complying with the requirements of the National Historic Preservation Act (1966), as amended, and its associated regulations.

More specifically, the objectives of the building inspection, including the geophysical study, are as follows:

1. To identify all potential "compartments" in which contaminants of concern may be present;

2. To document the location, dimensions, physical condition, accessibility, and any other relevant attributes of each compartment;

3. To collect information about the design and construction of the building that is needed for the final demolition plan;

4. To locate, identify, and obtain copies of historical records that provide additional information regarding the location of potential contamination within and near the building, as well as information pertaining to the design and construction of the building and its support systems (heating, ventilation, and air conditioning [HVAC]; sewage; electrical power; water; and other specialized systems, such as steam, compressed gas, etc.); and

5. To document, in a report, the findings of the inspection team for future use in developing the field sampling plan, the preliminary risk assessment, and the demolition plan. 


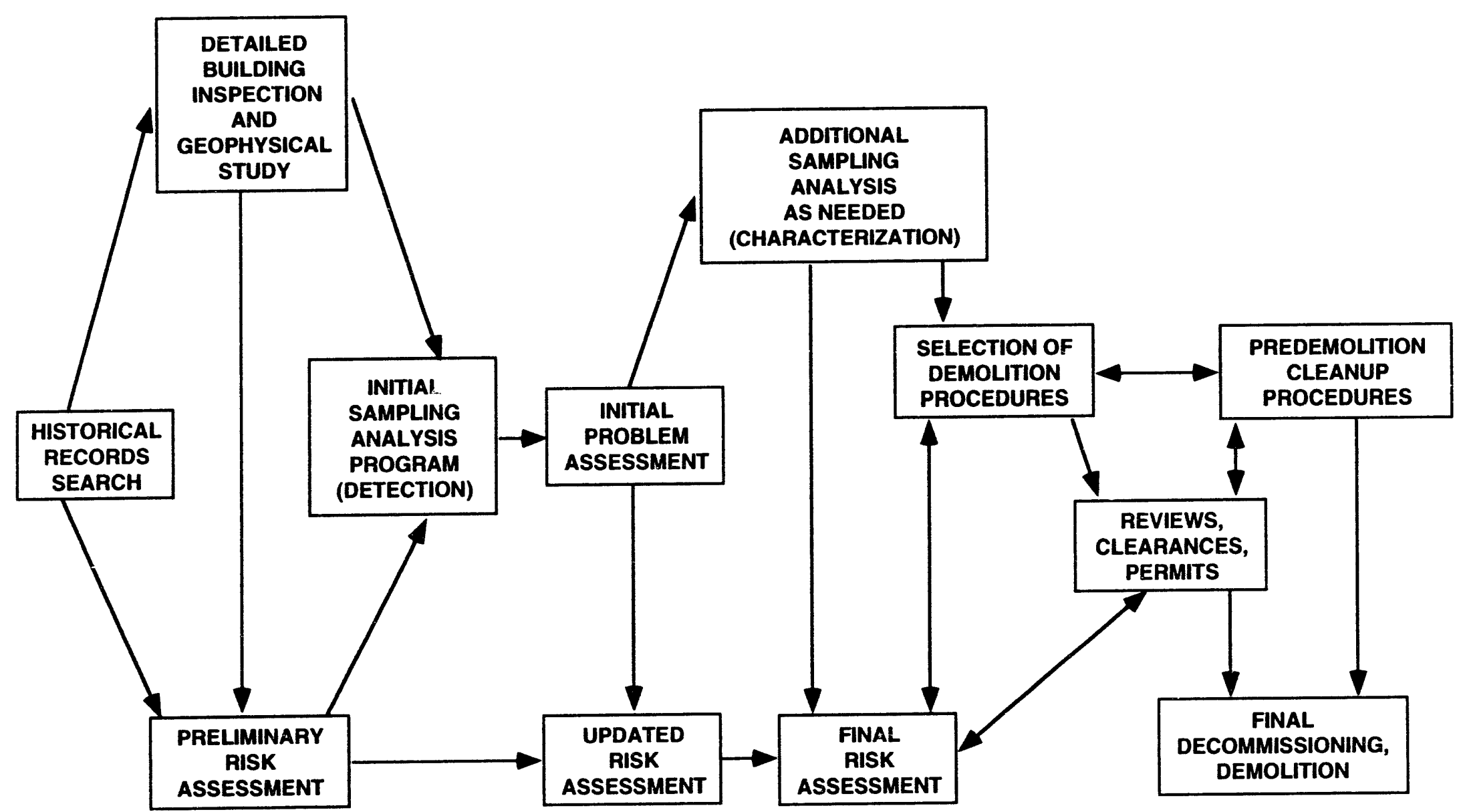

FIGURE 2 Decommissioning Process for Buildings at Aberdeen Proving Ground 
In this context, the term compartment denotes any generic or specific location or medium in which contamination may be found. Potential compartments include, but are not limited to, the following:

1. Interior of the building

a. Ventilation system - ducts, filters, blowers, vents, screens, hoods, etc.;

b. Drainage system - collection points, such as traps, sumps, and low areas in lines; areas below the floor in the vicinity of the underground drainage system;

c. Process-related equipment - piping, tanks, and pumps that are still present; and

d. Potential spillage areas*

(1) Floors - Cracks, collection points, low areas, and high-spillprobability areas;

(2) Walls (up to approximately $8 \mathrm{ft}$ above floor level) - nonporous as well as porous materials in high-spill-probability areas.

2. Exterior to the building

a. Underground tanks, pipelines, and other underground structures;

b. Sumps;

c. Ditches and drainage channels, especially near points at which releases from inside the building may have occurred;

d. Areas along underground drainage and sewer lines;

e. Areas in and around concrete pads (transformer pads, storage areas, etc.);

* The nature of the material in a spill area is important because porous materials could contain contamination. Porous materials include cement, grouting, wood, and wallboard. Residual contamination may be present on the surfaces of nonporous materials. 
f. Areas in the vicinity of major electrical connections/components (for polychlorinated biphenyl contamination); and

g. Areas in the vicinity of process-line connections with adjacent buildings. 


\section{Building Inspection Methodology}

The activities required to produce the initial building-inspection report can be divided into four groups: (1) conduct a historical records search, (2) detect and investigate by geophysical methods any underground structures associated with the building, (3) conduct a detailed visual inspection of the internal and external areas of the building, and (4) consolidate the information into a final inspection report.

A preliminary visit to the site prior to the actual inspection visit can be useful. The objectives of the preliminary visit are to obtain engineering drawings for the buildings to be inspected, identify health and safety issues that need to be addressed, discuss and resolve access restriction issues, identify needed support services, and identify potential problems that might hinder the execution of the inspection or the geophysical investigations. Photographs may be taken of the exterior of the buildings for use in pianning the inspection visit. However, all photographs must be reviewed by an APG censor prior to their release, and adequate time must be allowed for this review in scheduling the work.

Following the preliminary site visit, an inspection work plan and an associated health and safety plan are prepared for the specific building to be inspected. After APG staff reviews and approves these plans, the inspection can be conducted. Because of scheduling constraints and other considerations, it is convenient to prepare separate work and health and safety plans for the geophysics investigations, which take place entirely out-of-doors, and for the visual building inspections, which take place largely inside the buildings. It is desirable but not essential that the geophysics investigation be conducted simultaneously with the visual building inspection; currently, separate teams of ANL staff are involved in the two activities.

Specially designed, preprinted logbooks are used for building inspections. Each page in these logbooks poses specific questions concerning the building construction, mechanical systems, HVAC systems, remaining processing equipment, and other pertinent matters. The logbook is filled out by the investigation team during the building inspection. The logbook format is set up in such a way that the information gathered in the field is compiled in an orderly manner for each of the subject buildings. This method of compiling data enables the members of the inspection team to translate the field data into an inspection report efficiently and consistently. 


\section{Summary of Historical Records Search for Building E5375}

The historical records for Building E5375 indicate that this building was planned and constructed in the early part of 1941 as a benzene storage facility for the $\mathrm{CN}$ (chloroacetophenone) Production Complex No. 2, a tear-gas production facility in the Edgewood/Canal Creek area at APG (EAI Corporation 1989). The records also show that Building E5375 was planned and constructed concurrently with Building E5190 and that the structural aspects of these buildings are identical. Building E5375 was actively used by the Army as a benzene storage facility from the time of its completion in 1942 until 1944. In 1944, the building was put on standby status, and it remained in this status until 1948, when the CN Production Complex No. 2 war leased to the Advanced Solvent Company. Army records indicate that this company used the tan. $s$ in Building E5375 for storage of benzene until 1950. There is no record of the building being used for any purpose after 1950. No evidence was found to indicate that the storage tanks in Building E5375 were ever cleaned or decommissioned. The original engineering drawings used during the construction of Building E5375 correspond with its present-day configuration. It is concluded that no major modifications were ever made to Building E5375 and that the engineering documents for this building are up-to-date. 


\section{Description of Building E5375}

This section contains a general description of Building E5375 and its contents and detailed descriptions of all significant features of the building. Figure 3 shows the location of Building E5375 in relation to the overall production area in the Edgewood area at APG, and Figure 4 shows Building E5375 in relation to other structures in its immediate vicinity.

Building E5375 is a one-room, single-story structure constructed of cast-in-place concrete. All four walls and the floor of Building E5375 are 1-ft-thick concrete (Whitman, Requardt, and Smith Engineers 1941a,b,c). The roof of the structure is constructed of lightweight structural steel covered with corrugated sheet metal. The exterior walls of the structure extend from the floor slab, which lies $4 \mathrm{ft}$ below ground level, to the roof line. The building has a total of seven windows; six of these windows are of standard design, measuring $84 \mathrm{in.tall} \times 78 \mathrm{in}$. wide and consisting of a metal framework with multiple panes of glass. The seventh window is of the same design but is somewhat narrower than tis: other windows. Mounted below each window is an accompanying vent.

Building E5375 contains three sets of double doors. A set of $10 \mathrm{ft} \times 10 \mathrm{ft}$ double doors is located in the west wall of the building, and a set of $8 \mathrm{ft} \times 8 \mathrm{ft}$ double doors is in the east wall of the building. These doors are aligned with the two main tanks within the building and may have been intended to facilitate the installation or changing of the main tanks. The third set of double doors is in the south wall of the building and serves as the main entrance to the building. Constructed of wood cores covered with reinforced metal skins, the doors of this building are designed to withstand fire and would not fragment or splinter in the event of an explosion.

The building contains three storage tanks: two horizontal liquid storage tanks of approximately 10,000-gal and 3,000-gal capacity, and a third, vertically oriented tank on an elevated platform near the building entrance. Both of the horizontal tanks rest on supports located on the building floor, while the elevated platform is at ground level. Most of the process piping in the building has been disconnected and removed.

Building E5375 was designed for use as a flammable-liquid storage facility. The floor of the building was placed below grade, and the 1-ft-thick concrete walls and floor for the building were cast monolithically (i.e., in one piece). In the event of an explosion, this building would vent most of the initial force upward, thus containing the force of the explosion to the immediate area of the building. This design also allowed Building E5375 to act as a primary containment pool if one of the tanks ruptured and leaked.

The building HVAC system consists of a single, roof-mounted, electrically powered exhaust fan. This fan and its associated duct work are located in the northeast corner of the building. A series of large wall vents, located below each of the windows in the building, supply an abundant quantity of fresh air. At one time, wind-driven turbine vents were located on the roof 


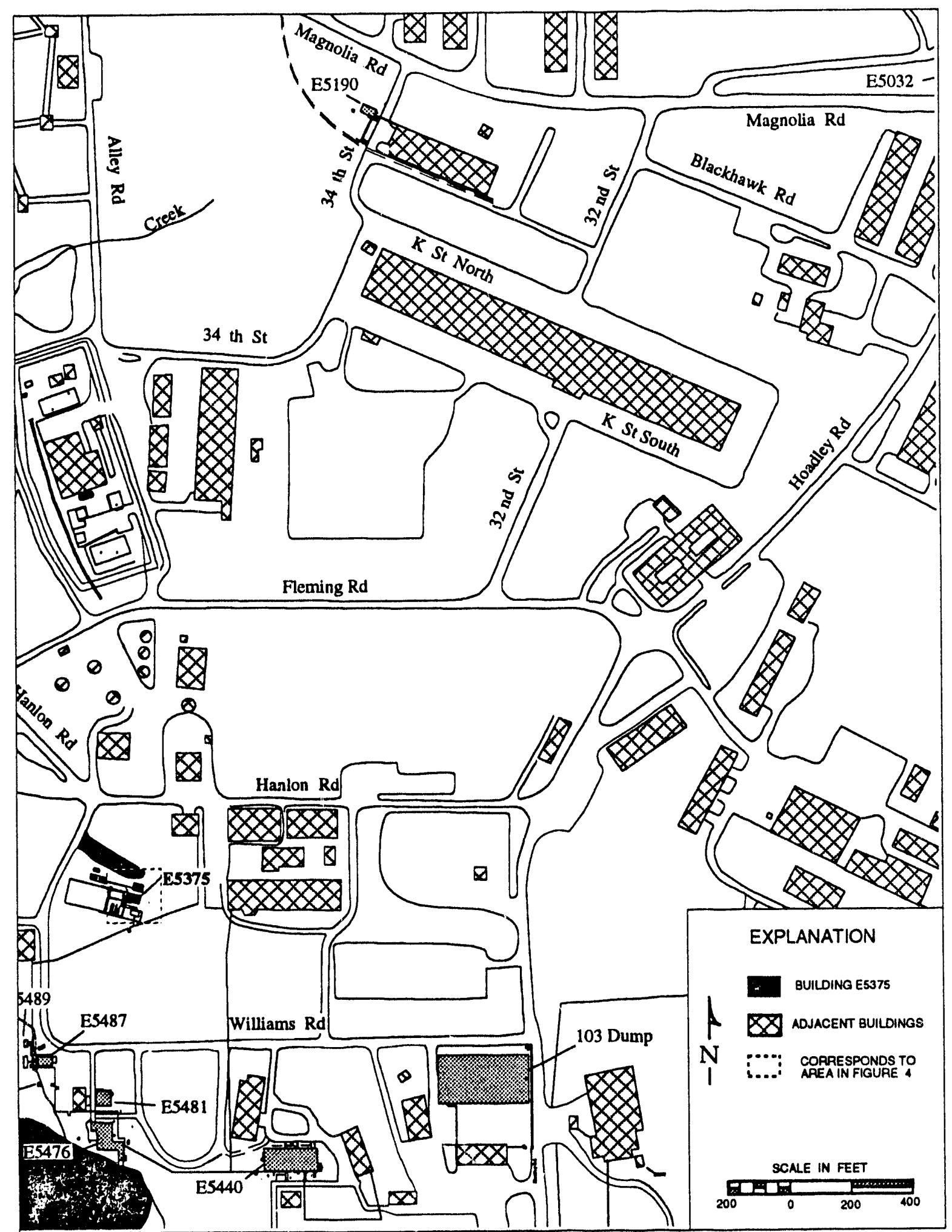

FIGURE 3 General Site Map of Aberdeen Proving Ground in the Vicinity of Building E5375 


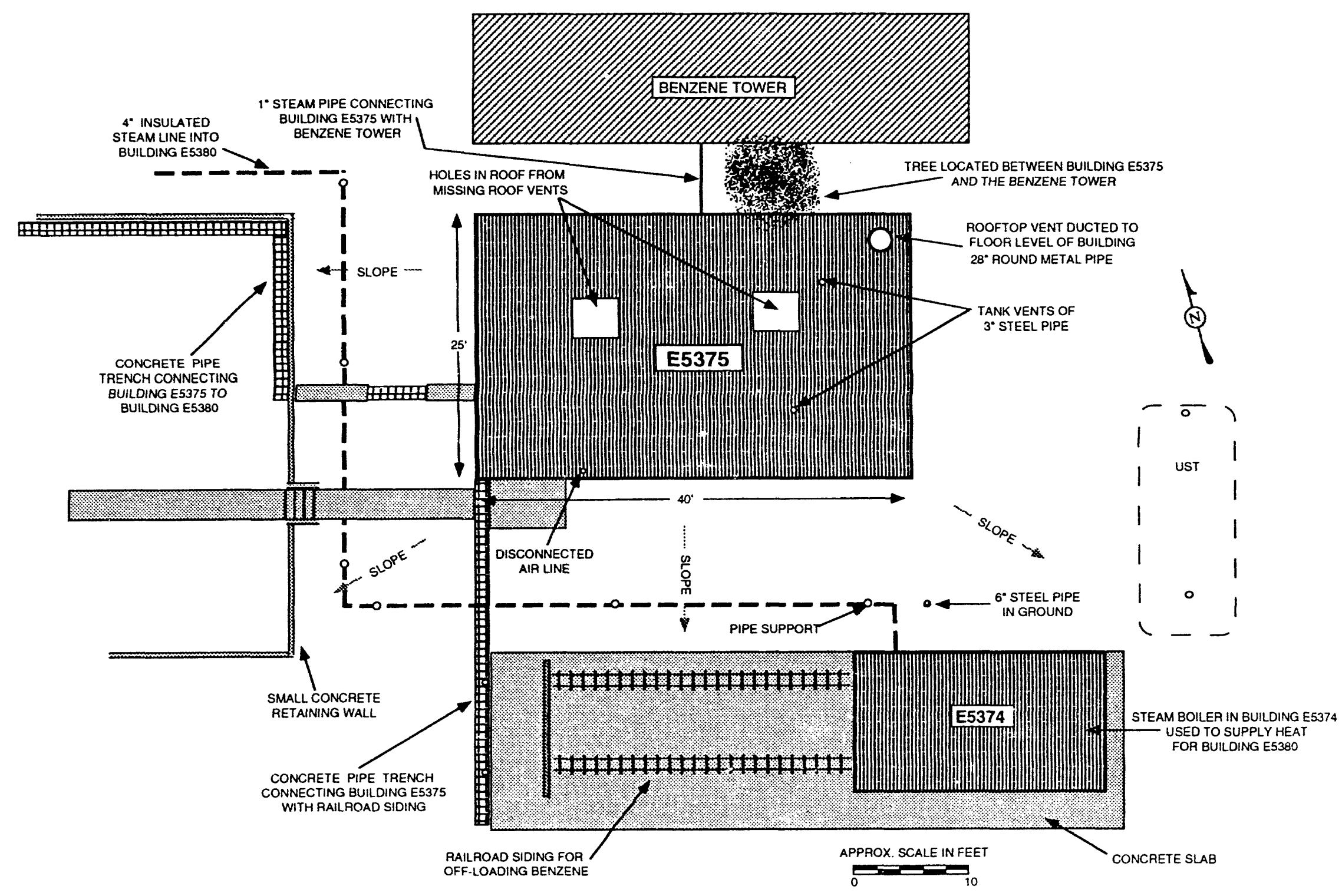

FIGURE 4 Building E5375 Site Plan 
of the building, but these vents were removed, and the resulting holes in the roof were never sealed. This condition allows rainwater to enter the building and has caused the roof of the building to deteriorate significantly.

The building contains two floor drains. The outfall piping for these drain lines was not located during either the building investigation or the geophysical survey. Both of these drain traps were wet at the time of the building inspection, indicating that these drain lines are functional.

A pipe trench connects Building E5375 with the railroad siding directly to the south of the building. Another pipe trench connects the building with the adjacent, main $\mathrm{CN}$ production building (Building E5380). These trenches contain pipes that were used for pumping benzene from tank cars at the siding into Building E5375 and from Building E5375 to Building E5380.

The current condition of Building E5375 is fair, and, except for the roof, the building is structurally sound.

\subsection{Site Description}

\subsubsection{Address}

Building E5375 is located east of Williams Road and immediately south of Hanlon Road, in the Edgewood/Canal Creek area of Aberdeen Proving Ground (see Figure 3).

\subsubsection{Proximity to Other Buildings}

This building is part of the CN Production Complex No. 2 at that same location (Figures 3 and 4).

\subsubsection{Exterior Footprint Dimensions}

Building E5375 is $40 \mathrm{ft}$ long $\times 25 \mathrm{ft}$ wide (see Figure 4). 


\subsubsection{Surface Soils and Topographical Conditions}

The area directly surrounding Building E5375 is flat and dry, with a gentle slope away from the building to the south. The surface soils surrounding the building are sandy and loose and covered thinly by grass.

\subsubsection{Vegetation in the Immediate Vicinity}

The building is covered with climbing vines at the east end. There is one tree, approximately 20-30 ft in height, directly to the north, between Building E5375 and the Benzene Tower.

\subsubsection{External Aboveground Structures or Equipment}

Directly to the north of Building E5375, there is a large structure known as the Benzene Tower. This structure is apparently a cooling tower (Whitman, Requardt, and Smith Engineers 1941a) and is connected to Building E5375 by a single overhead pipe (Figure 4).

\subsubsection{Connections with Adjacent Buildings}

Building E5375 is connected to the $\mathrm{CN}$ production facility, Building E5380, by a belowgrade concrete pipe trench covered with removable 1/4-in. diamond-plate steel panels, each about $4 \mathrm{ft}$ long (Figure 4). This trench extends from the west side of Building E5375 for approximately $80 \mathrm{ft}$ and enters the east side of Building E5380. The trench still houses two 2-in. pipes that were used to supply benzene when this facility was operational. The pipe trench is constructed of castin-place concrete approximately 3 in. thick $\times 24$ in. wide. Building E5375 is also connected to a two-track railroad siding $30 \mathrm{ft}$ south of the building by a similar pipe trench (Figure 4); the present number and size of the pipes in this trench are unknown, but provision is made in the steel cover plates for a connection to each of the two railroad tracks. An existing engineering drawing (Whitman, Requardt, and Smith Engineers 1941a) shows that, at one time, three pipes connected Building E5375 with Building E5380 and that two pipes were present in the trench to the railroad siding. In each trench, one of the lines was a steam line. The railroad siding is no longer operational. The siding appears to have been the point where benzene was pumped from railroad tank cars into the storage tanks located in Building E5375. The depth of the two pipe trenches could not be accurately determined at the time of the building inspection because they contain silt and, in some areas, large patches of poison ivy, but they are believed to be no more than 20 in. deep. 


\subsubsection{Location and Type of Underground Structures}

Approximately $40 \mathrm{ft}$ to the southeast of Building E5375 there is an underground storage tank. APG records indicate that this tank is a 10,000-gal fuel-oil storage tank (APG No. 91606) for a steam boiler located in Building E5374 (Figure 4) and is not associated with Building E5375.

\subsubsection{Location and Type of Surface Drainage System}

The area around Building E5375 is not served by any type of surface or storm drainage system.

\subsubsection{Utility Access Points (Manholes) and Utility Type}

There is no underground utility system associated with Building E5375.

\subsubsection{Piping Exiting the Building and Entering the Ground}

See Section 4.1.7.

\subsubsection{Location and Direction of Nearby Roads and Sidewalks}

Building E5375 has a concrete entrance slab at the south entrance to the building. There are no access or service roads that directly serve this building.

\subsection{North Exterior Elevation}

\subsubsection{Dimensions}

The north elevation of Building E5375 measures $14 \mathrm{ft} 8$ in. tall $\times 40 \mathrm{ft}$ wide (Figure 5). 


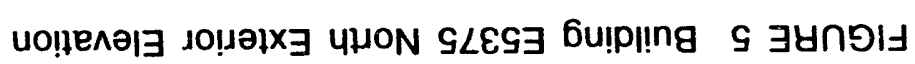

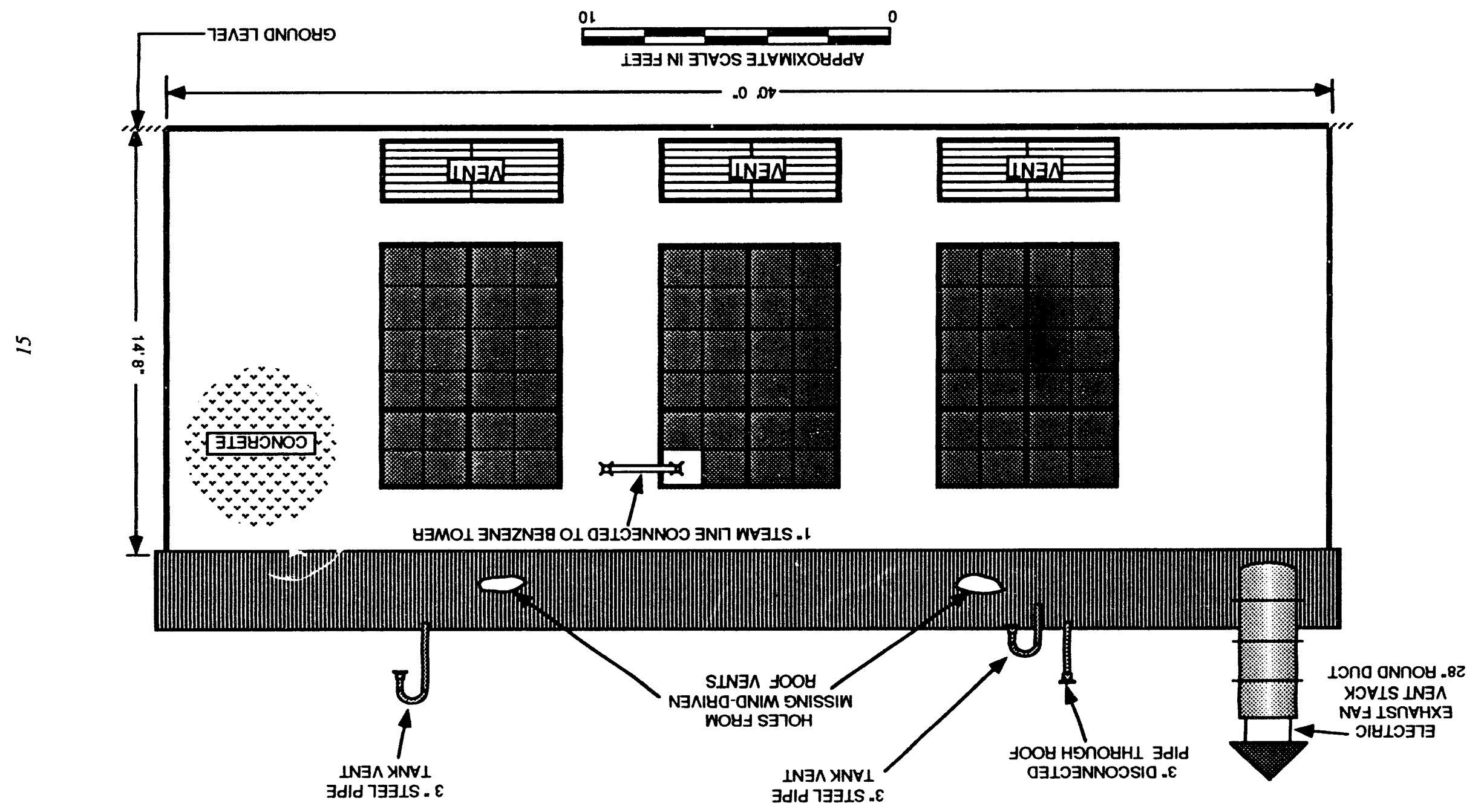




\subsubsection{Material of Construction}

The exterior walls of the building are 1-ft-thick, cast-in-place, steel-reinforced concrete.

\subsubsection{Doors and Windows}

No doors are present in this elevation. There are three window/vent combinations in the north elevation of Building E5375 (Figure 5).

\subsubsection{Piping along or Connected with this Face of the Building}

A single 1-in. steam line (Whitman, Requardt, and Smith Engineers 1941a) enters the building through the upper right pane (as viewed from outside the building) of the center window (see Figure 5). This pipe connects Building E5375 to the Benzene Tower located approximately $10 \mathrm{ft}$ to the north (Figure 4). The pipe is bent in the middle and has a remnant of insulation material wrapped around it at the bend.

\subsubsection{Utility Connections}

All utilities to Building E5375 have been disconnected. No former utilities are present in this elevation.

\subsubsection{External Equipment or Structures}

See Section 4.2.4.

\subsubsection{Vegetation}

Located between Buildings E5375 and E5380 is a single tree, approximately 20-30 ft in height (Figure 4).

\subsubsection{Overall Condition}

The overall condition of this elevation of the building is good. All of the components that constitute this elevation remain in place at the time of this investigation. 


\subsection{East Exterior Elevation}

\subsubsection{Dimensions}

The height of Building E5375 in the east elevation measures $18 \mathrm{ft} 6 \mathrm{in}$. at the south end of the roof and decreases to $14 \mathrm{ft} 8 \mathrm{in}$. at the north end. The overall width of the building in this elevation is $25 \mathrm{ft}$ (Figure 6).

\subsubsection{Material of Construction}

The exterior walls of the building are 1 -ft-thick, cast-in-place, steel-reinforced concrete.

\subsubsection{Doors and Windows}

The east elevation of Building E5375 contains one set of double doors, measuring $8 \mathrm{ft} \times 8 \mathrm{ft}$. These doors appear to be constructed of wood cores wrapped with a metal covering (Figure 6).

There is a single window/vent combination in the east elevation of Building E5375 (Figure 6). The window measures 84 in. tall $\times 78$ in. wide, and a 24 -in. tall $\times 78$-in. wide vent is mounted directly below it.

\subsubsection{Piping along or Connected with this Face of the Building}

This elevation of Building E5375 has no exterior piping, and there is no evidence that any piping has ever been attached to the exterior of the elevation.

\subsubsection{Utility Connections}

All utilities to Building E5375 have been disconnected. No former utilities are present in this elevation.

\subsubsection{External Equipment or Structures}

No external equipment or structures are present in the east elevation. 


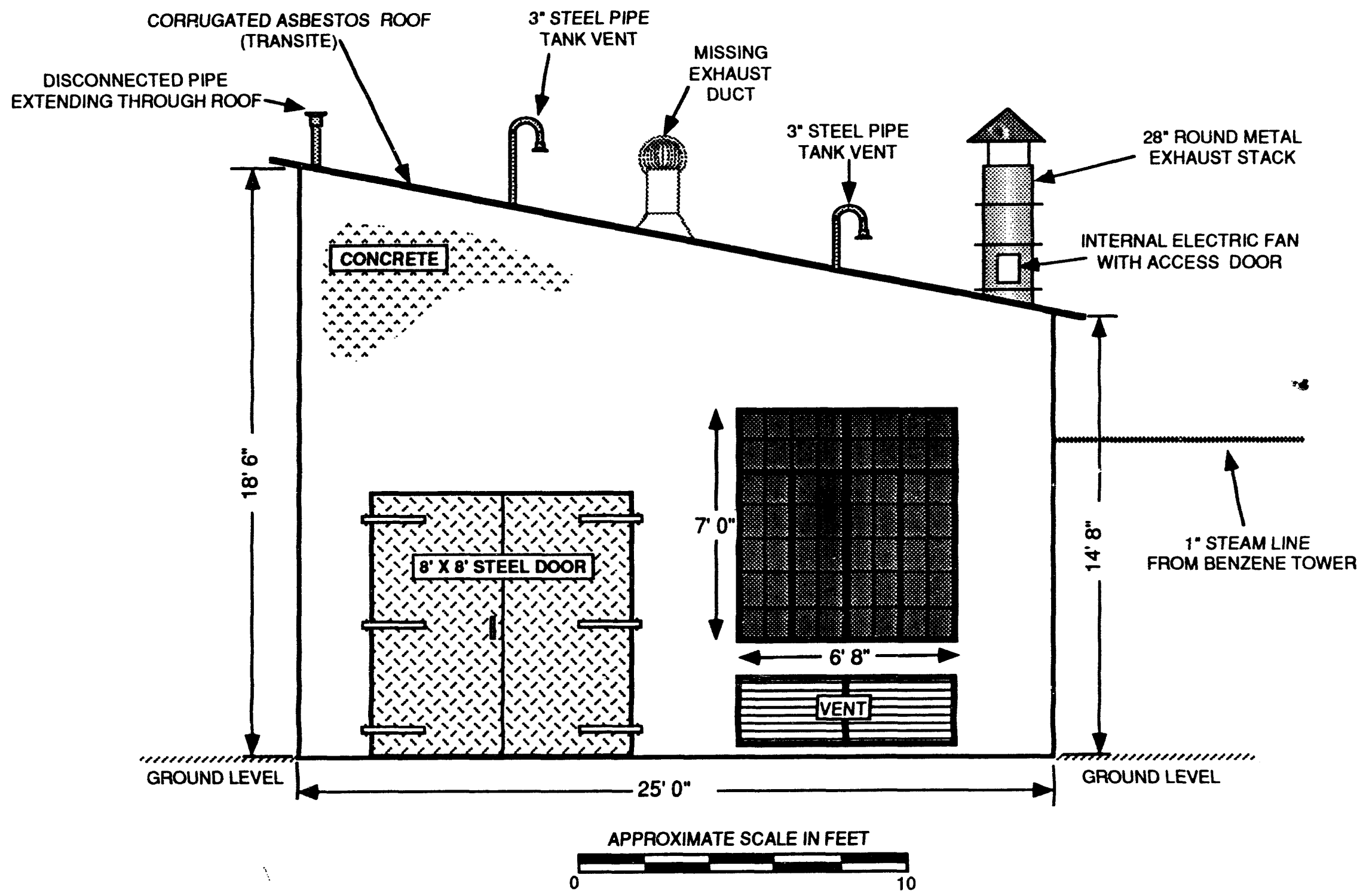

FIGURE 6 Building E5375 East Exterior Elevation 


\subsubsection{Vegetation}

The north end of the east elevation of Building E5375 is covered with climbing vines.

\subsubsection{Overall Condition}

The overall condition of this elevation of the building is good. All of the components that constitute this elevation remain in place at the time of this investigation.

\subsection{South Exterior Elevation}

\subsubsection{Dimensions}

The south elevation of Building E5375 measures $18 \mathrm{ft} 6$ in. tall $\times 40 \mathrm{ft}$ wide (Figure 7).

\subsubsection{Materisl of Construction}

The exterior walls of the building are 1-ft-thick, cast-in-place, steel-reinforced concrete.

\subsubsection{Doors and Windows}

The south elevation of Building E5375 contains one set of double doors, measuring $8 \mathrm{ft} \times 8 \mathrm{ft}$. These doors appear to be constructed of wood cores covered with metal. There are two window/vent combinations in the south elevation of Building E5375 (Figure 7).

\subsubsection{Piping along or Connected with this Face of the Building}

This elevation of Building E5375 is - Irrently devoid of any exterior piping, but evidence of former pipe connections in this elevation remains in the form of holes through the exterior walls of the building (Figure 7).

The pipe trench that connected Building E5375 with the railroad siding to the south of the building (Figures 4 and 7 ) exits at the southwest corner. 


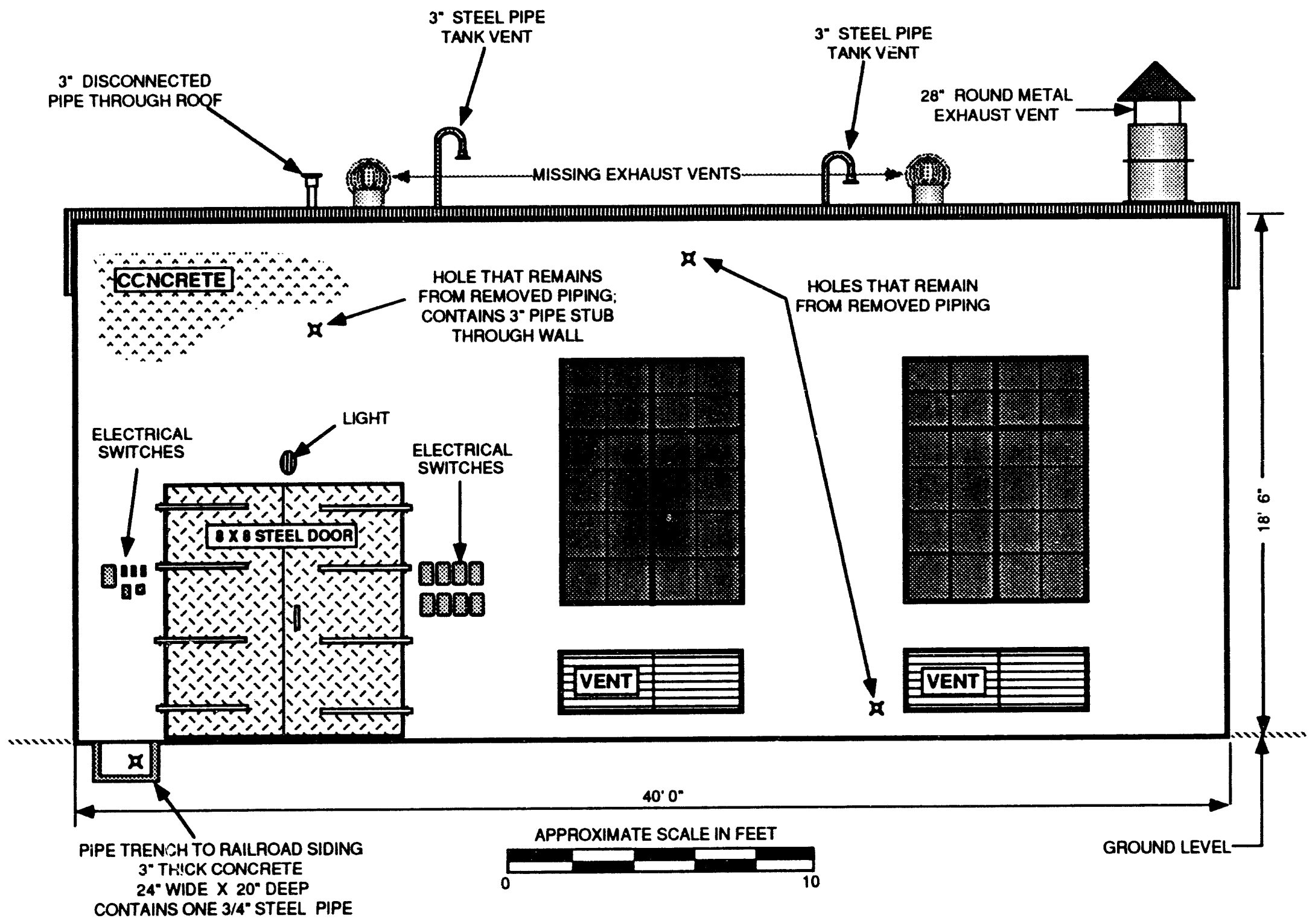

FIGURE 7 Building E5375 South Exterior Elevation 


\subsubsection{Utility Connections}

All utilities to Building E5375 have been disconnected. No former utilities are present in this elevation.

\subsubsection{External Equipment or Structures}

Present in this elevation of Building E5375 are a number of electrical control boxes located on both sides of the main entrance doois (see Figure 7).

\subsubsection{Vegetation}

No vegetation is present in the south elevation.

\subsubsection{Overall Condition}

The overall condition of this elevation of the building is good. All of the components that constitute this elevation remain in place at the time of this investigation.

\subsection{West Exterior Elevation}

\subsubsection{Dimensions}

The height of the west elevation of Building E5375 measures $18 \mathrm{ft} 6 \mathrm{in}$. at the south end of the roof and decreases to $14 \mathrm{ft} 8 \mathrm{in}$. at the north end; the overall width of the building in this elevation is $25 \mathrm{ft}$ (Figure 8).

\subsubsection{Material of Construction}

The exterior walls of the building are 1-ft-thick, cast-in-place, steel-reinforced concrete. 


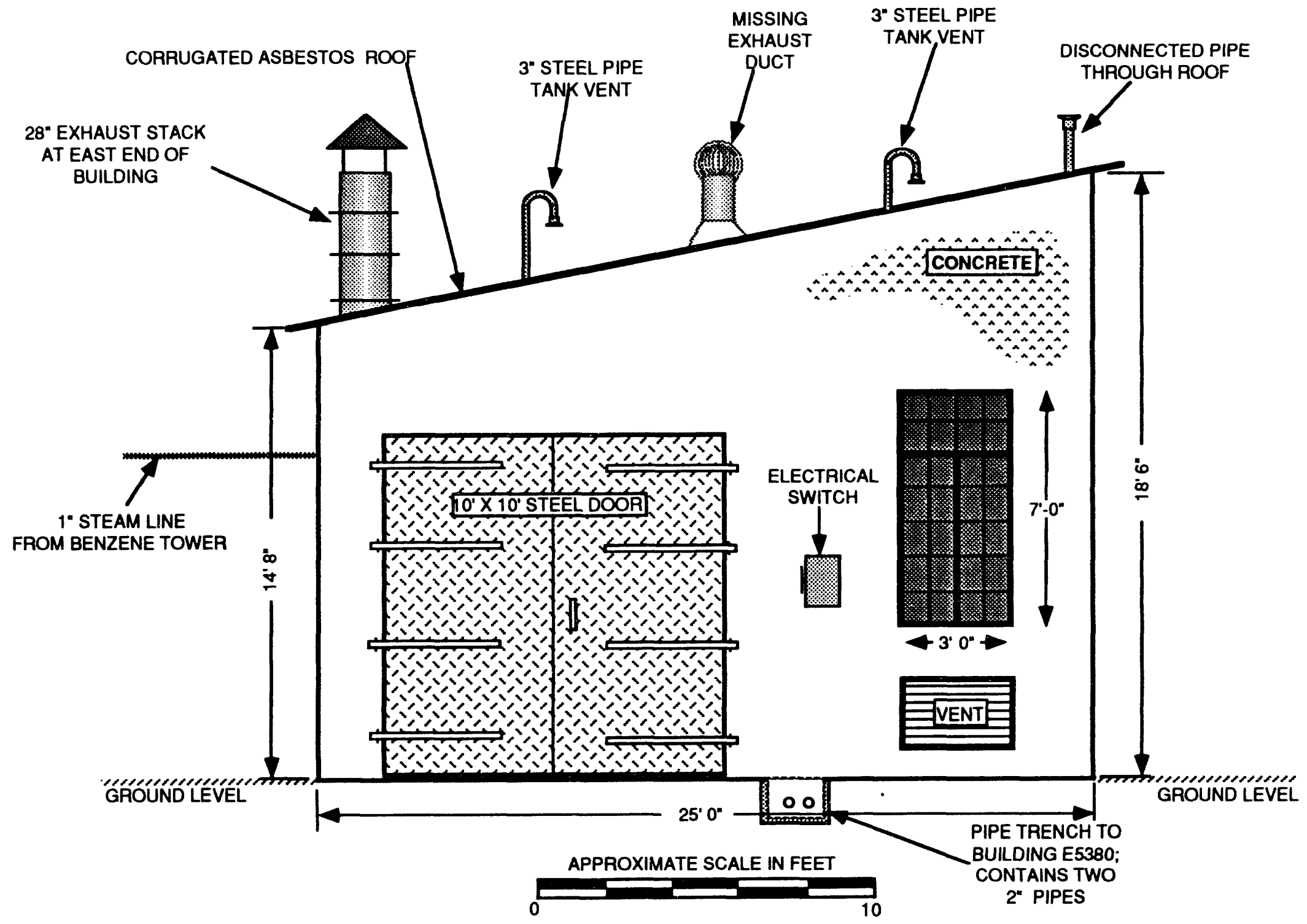

FIGURE 8 Building E5375 West Exterior Elevation 


\subsubsection{Doors and Windows}

The west elevation of Building E5375 contains one set of double doors, measuring $10 \mathrm{ft} \times 10 \mathrm{ft}$. These doors appear to be constructed of wood cores wrapped with a metal covering.

The only nonstandard window in Building E5375 is in the west elevation (Figure 8). This window is identical in design to all other windows in this structure but measures only $7 \mathrm{ft}$ tall $\times$ $3 \mathrm{ft}$ wide. This window also has an associated vent mounted below it that measures 24 in. tall $x$ 36 in. wide.

\subsubsection{Piping along or Connected with this Face of the Building}

The west elevation of Building E5375 is devoid of exterior piping or evidence of any former piping. Exiting the building from this elevation is an underground, open-top, concrete trench that contains two metal pipes. This pipe trench was used to transport a benzene-aluminum chloride mixture from Building E5375 to Building E5380 (Figure 8).

\subsubsection{Utility Connections}

All utilities to Building E5375 have been disconnected. No former utilities are present in this elevation.

\subsubsection{External Equipment or Structures}

No external equipment or structures are present in the west elevation.

\subsubsection{Vegetation}

No vegetation is present in the west elevation.

\subsubsection{Overall Condition}

The overall condition of this elevation of the building is good. All of the components that constitute this elevation remain in place at the time of this investigation. 


\subsection{Roof}

\subsubsection{Type and Dimensions}

Building E5375 has a shed-type roof measuring $42 \mathrm{ft}$ long $\times 27 \mathrm{ft}$ wide.

\subsubsection{Height}

The high (north) end of the roof at Building E5375 is $18 \mathrm{ft} 6 \mathrm{in}$. above ground level; the low (south) end of the roof is $14 \mathrm{ft} 8$ in. above ground level (Figure 5).

\subsubsection{Surface Materials}

The roof of Building E5375 is made of corrugated sheet metal (Whitman, Requardt, and Smith Engineers 1941b).

\subsubsection{Structural Materials Used in the Roof Support System}

The roof of Building E5375 is supported by a lightweight structural steel framework. This system uses a single load-bearing steel I-beam, which bisects the building on a north-south axis. This I-beam supports the steel roof joist, which is placed $2 \mathrm{ft}$ off center and extends from the I-beam to the east and west walls of the building.

\subsubsection{Condition}

The roof of Building E5375 contains two holes, each approximately $2 \mathrm{ft}$ in diameter, at the center line of the roof. These holes resulted from the removal of two wind-driven exhaust vents that had once been mounted on the building roof (Figure 5).

\subsubsection{Equipment Located at, on, or in the Roof}

The fan motor for the building exhaust system is located in duct work that extends above the northeast corner of the roof. The vent stack is constructed of galvanized, 18-in. diameter, round duct work and is equipped with a conical top for protection from the weather. This vent stack extends approximately $10 \mathrm{ft}$ above the roof surface. 


\subsubsection{Chimneys, Roof Vents, or Vent Stacks}

Building E5375 has two tank-vent stacks passing through the roof. Each of these vents is a 3-in. steel pipe with half of a two-piece high-pressure flange attached to the upper end, and each is plumbed in a candy-cane configuration to exclude rainwater (Figure 5). The presence of the flanges indicates that the present vent stacks were once connected to pining that is no longer present. It is suspected that the present tank venting system was part of a steam or compressed-air pumping system used to transfer the contents of the tanks from Building E5375 to Building E5380. A small piece of this system remains intact in the form of a 3-in. pipe located over the entrance to the building. This pipe passes through the face of the building as well as the roof and is disconnected at both the interior and exterior sides (Figure 7). The 28-in. metal exhaust duct leading to the exhaust blower for the ventilation system also passes through the roof in the northeast corner.

\subsubsection{Present Piping and Evidence of Former Piping Located on the Roof}

All piping on the roof of Building E5375 is described in Section 4.6.7.

\subsection{Interior Floor Plan}

\subsubsection{Number and Dimensions of Interior Rooms}

Building E5375 is a single-story, one-room building with interior dimensions of $38 \mathrm{ft}$ long $\times 23 \mathrm{ft}$ wide. Figure 9 shows the floor plan.

\subsubsection{Room Perimeter Walls}

The walls of the room coincide with the exterior walls of the building, which are 1-ft-thick, cast-in-place, steel-reinforced concrete. These walls extend from the floor $(4 \mathrm{ft}$ below exterior grade) to the roof line of the building. They are in good condition with regard to their structural integrity. Figures 10-13 show the north, east, south, and west interior elevations, respectively.

\subsubsection{Floor Construction Materials, Condition, and Configuration}

Building E5375 has a 1-ft-thick, cast-in-place, concrete floor installed $4 \mathrm{ft}$ below the surrounding exterior grade of the building. The floor is intact and in good condition for its age. 


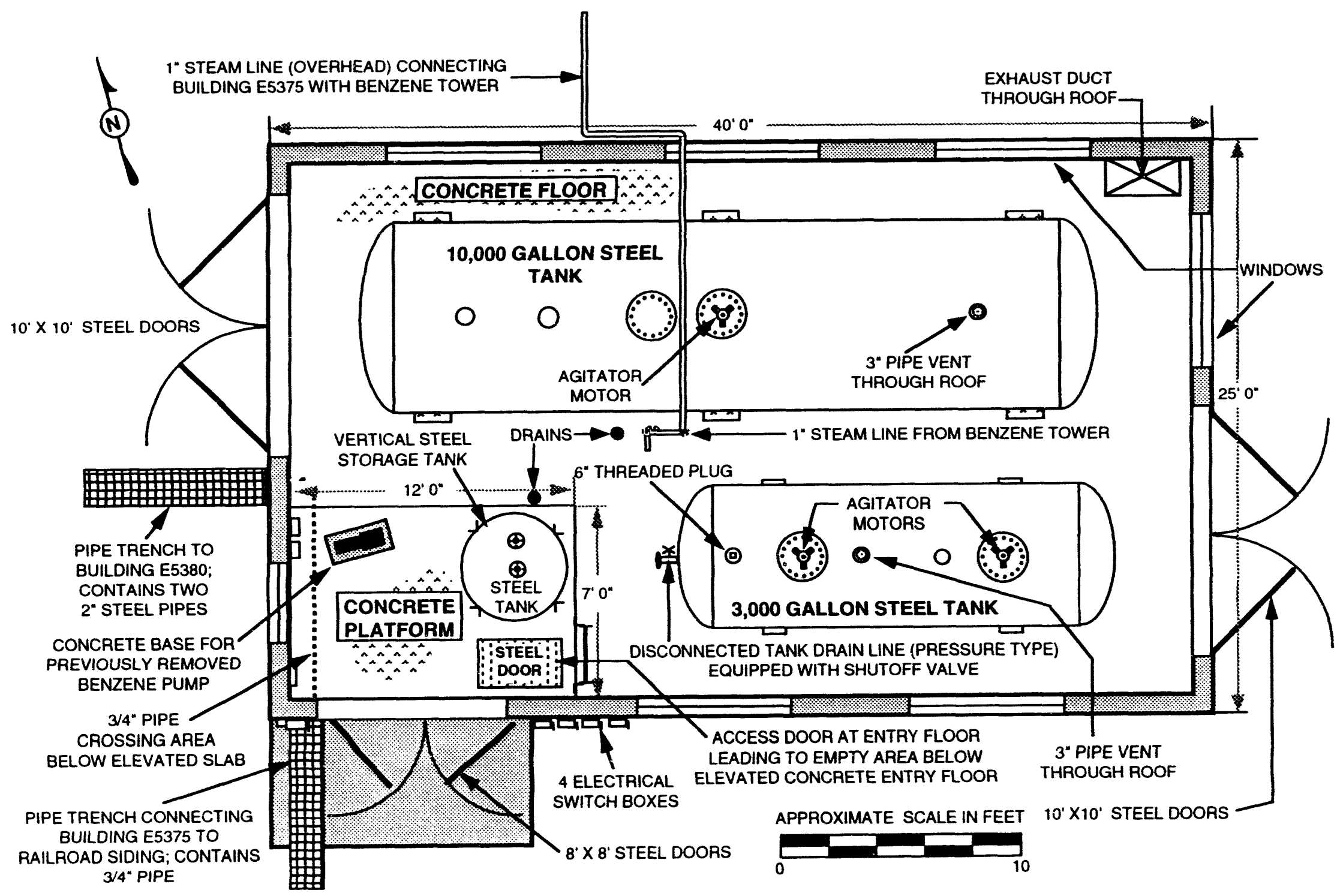

FIGURE 9 Building E5375 Floor Plan 


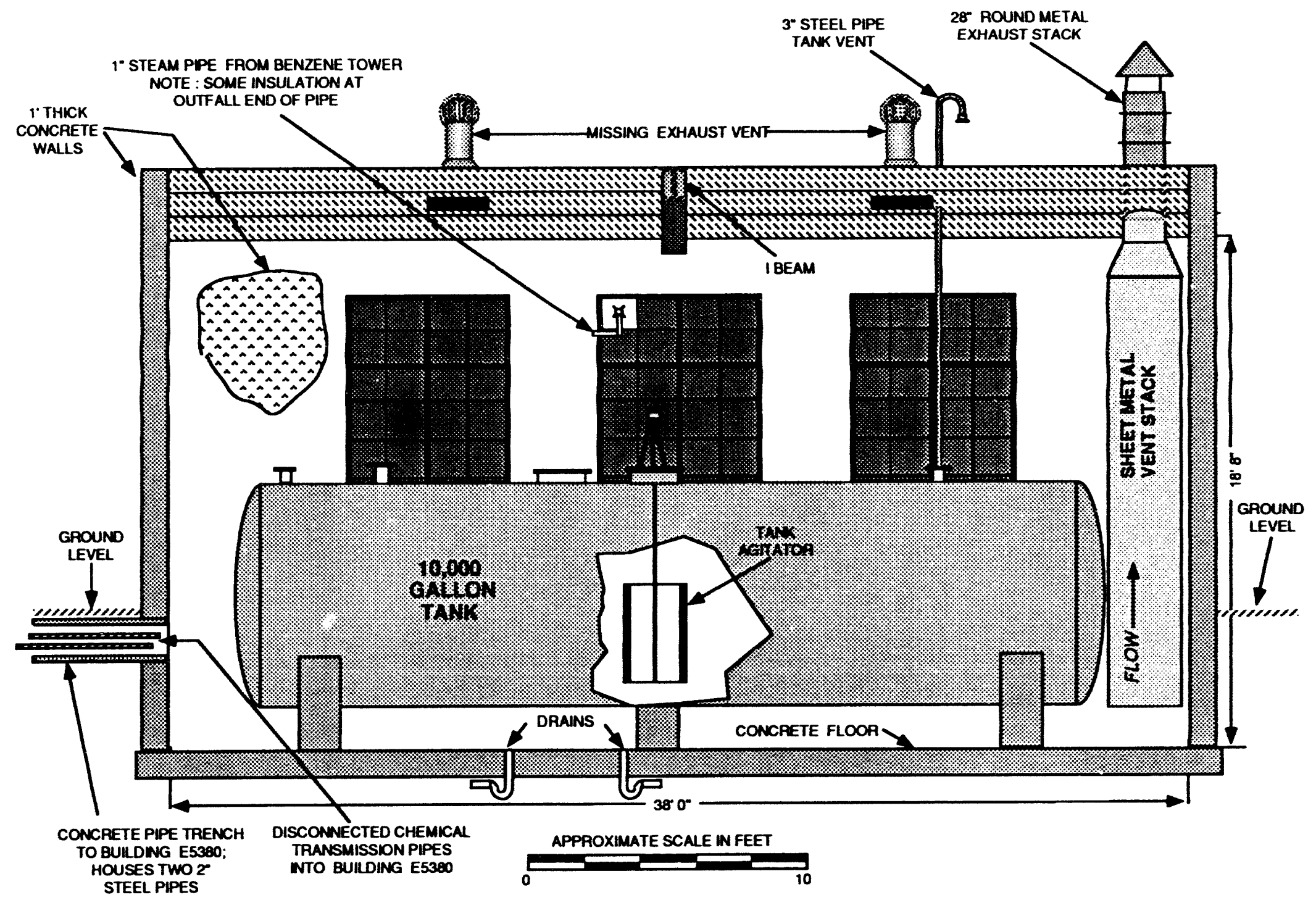

FIGURE 10 Building E5375 North Interior Elevation 


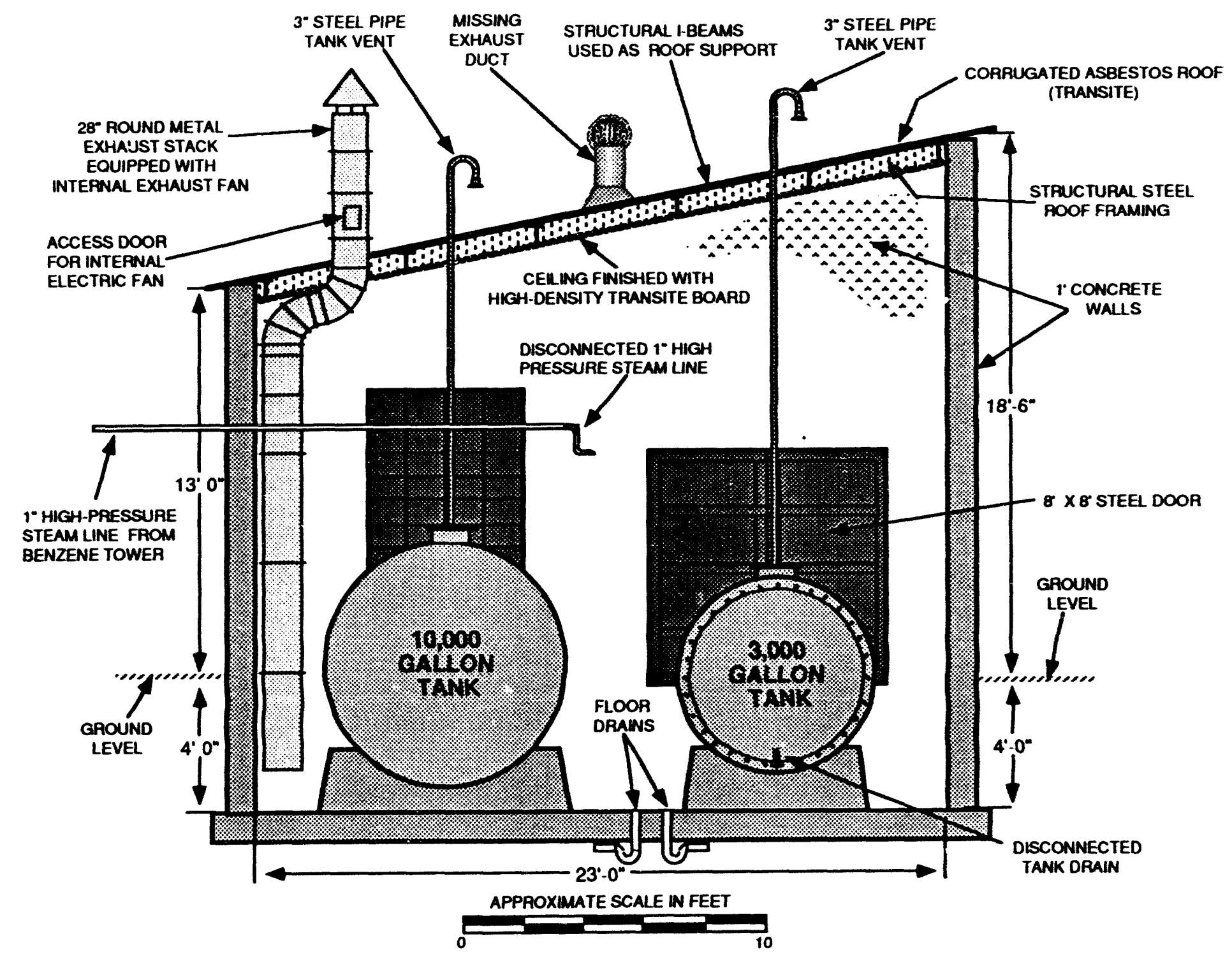

FIGURE 11 Building E5375 East Interior Elevation 


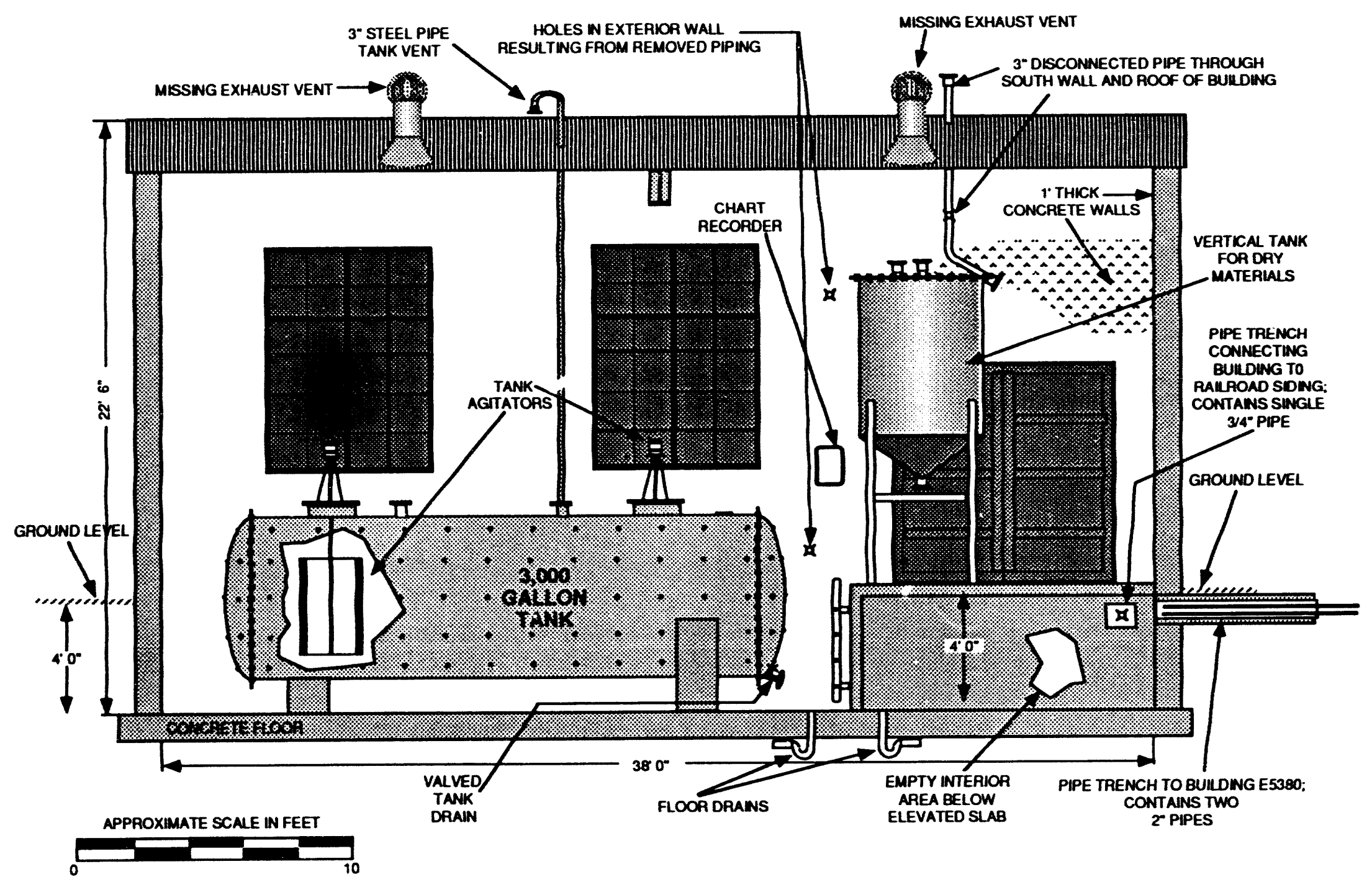

FIGURE 12 Building E5375 South Interior Elevation 


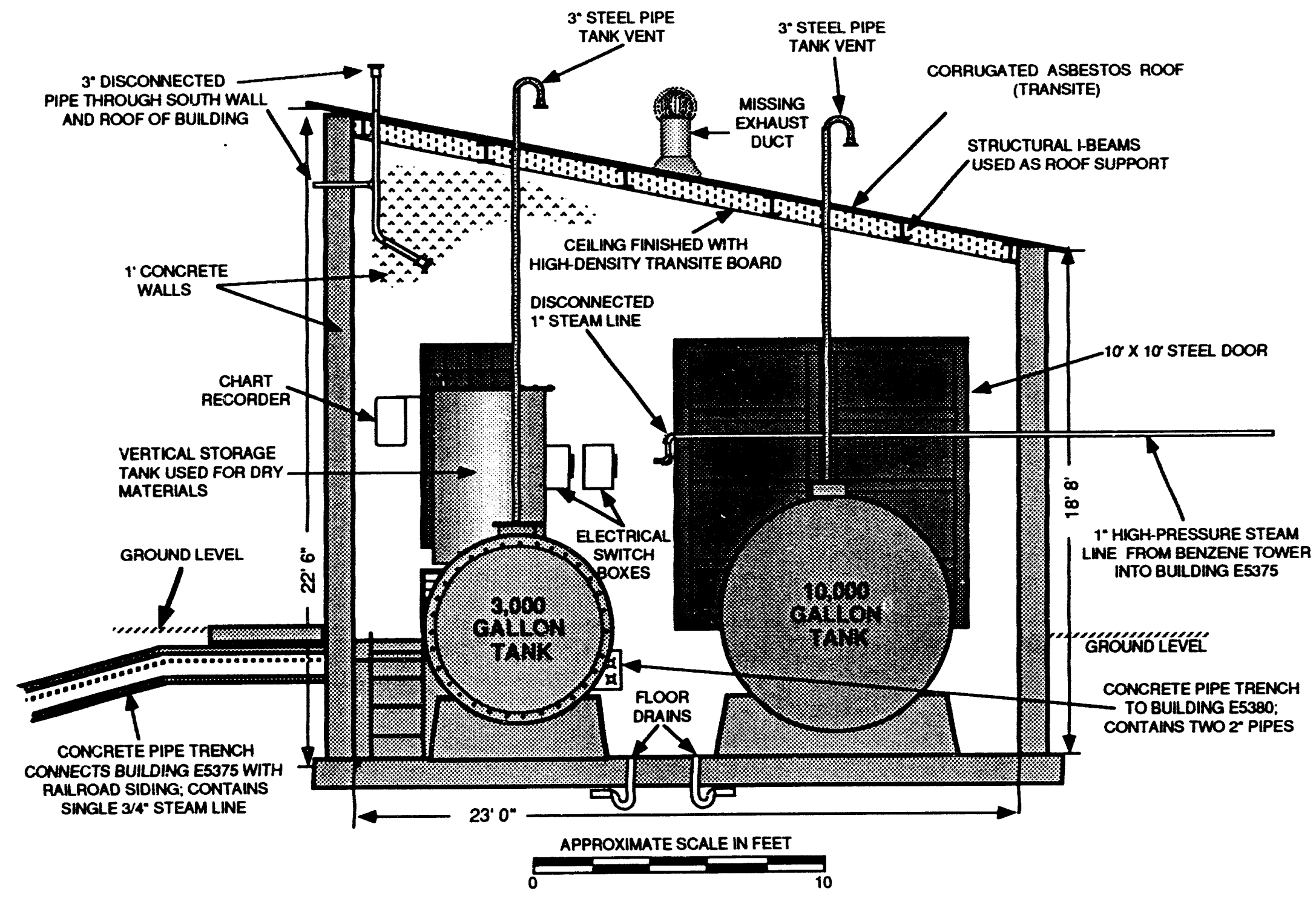

FIGURE 13 Building E5375 West Interior Elevation 
There is no evidence to suggest that the floor was modified in any way. No major cracks were identified.

In the southwest corner of the building, there is a $7 \mathrm{ft} \times 12 \mathrm{ft}$ concrete platform elevated approximately $4 \mathrm{ft}$ above the floor. The main entrance to the building leads onto this platform. A ladder leads down to the floor level of the building (Figure 13). This platform seems to have been the main work area within the building. The area underneath the platform is empty, unused space. One 3/4-in. high-pressure steam pipe that was used in off-loading benzene from tank cars on the railroad sidings extends through a hole in the north side of the platform structure (Whitman, Requardt, and Smith Engineers 1941a; see also Figure 12).

\subsubsection{Floor Penetrations}

The building contains two $2-1 / 2$ in. floor drains (Figure 9). The outfall piping for these drain lines was not located during either the building inspection or the geophysical survey. Both of these drain traps were wet at the time of the building investigation, indicating that these drain lines are functional. The easternmost drain was used as a steam-line condensate drain (Whitman, Requardt, and Smith Engineers 1941a).

\subsubsection{Location and Size of Interior Partitions}

Building E5375 is a single-room structure containing no interior partitions.

\subsubsection{Equipment or Supplies Present}

Building E5375 contains three storage tanks. The approximate dimensions and the location of these tanks within the building are shown in Figure 9.

Tank No. 1 is a cylindrical, welded-seam, steel tank, with an approximate capacity of 10,000 gal, that is oriented horizontally and parallel with the long axis of the building. The side of this tank is approximately $4 \mathrm{ft}$ from the north wall. The tank has five connections in the top, four of which are capped (Figure 9), and has no other drain or pipe connection; from west to east, the first is a 1-1/2-in. capped connection, the second is a 6-in. capped connection, the third is an 18-in. capped portal, the fourth is an 18-in. portal containing a device that appears to be an agitator or stirrer, and the fifth is a 3-in. connection to a 3-in. pipe that extends upward through the roof (see Figure 10). All connections utilize a type of flanged connection hardware that is typically used when the contents of the piping will be under significant pressure.

Tank No. 2 is a cylindrical, riveted-plate, steel tank, with an approximate capacity of $3,000 \mathrm{gal}$, that is oriented horizontally and parallel to tank No. 1. The two tanks are 
approximately $4 \mathrm{ft}$ apart. This tank also has five ports in the top. From west to east, they consist of a 6-in. port with a threaded plug (probably an inspection port), an 18-in. portal with an agitator mounted on it, a 3-in. connection attached to a 3-in. pipe that extends upward through the roof, a capped 4-in. connection, and another 18-in. portal with an agitator mounted on it (Figure 12). All connections utilize the same type of high-pressure flanged connection observed for tank No. 1. A 3-in. pipe is connected to this tank near the bottom of the west end. This pipe, equipped with a shutoff valve, was formerly connected to other piping no longer present by the same type of highpressure flanged connection as seen previously. Tank No. 2 is tilted slightly to the west ( 3 in. over $10 \mathrm{ft}$ according to Whitman, Requardt, and Smith Engineers [1941c]); this is common practice when the tank contents are partially solid.

Tank No. 3 in Building E5375 is a cylindrical, welded-seam, steel tank with a conical bottom that is mounted on supports attached to the elevated platform at the entrance to the building (Figure 12). The capacity of this tank is approximately 500 gal. Two 2-in. open flanged connections are on the top of the tank.

Building E5375 also contains remnants of disconnected piping at various locations and several disconnected electrical switching devices, as shown in Figures 9-13. A 10 in. $\times 24$ in. sheet-metal exhaust duct that extends vertically from the ceiling down to 8 in. above the floor is located in the northeast corner of the building (Figure 11). The fan motor for this system is located in the part of the duct work that lies above the roof (see Section 4.6.6).

\subsection{North Interior Elevation}

\subsubsection{Wall Characteristics}

Refer to Section 4.7.2 for a description of the wall characteristics. See also Figure 10.

\subsubsection{Interior-Wall Finish Materials}

The interior walls of Building E5375 are raw or uncoated concrete.

\subsubsection{Piping Attached to or Associated with the Wall}

A single 1-in. steam pipe enters the building through the upper left pane (as viewed from inside) of the center window (Figure 10). This pipe is connected to the Benzene Tower (see Section 4.2.4). 


\subsubsection{Equipment Connected with this Elevation}

Refer to Section 4.7 .6 for discussion of the equipment associated with this elevation. See also Figures 5, 9, and 10 .

\subsubsection{Doors and Windows}

There are no doors in the north elevation of this building. Refer to Section 4.2.3 of this report for a window description. See also Figures 5 and 10.

\subsection{East Interior Elevation}

\subsubsection{Wall Characteristics}

Refer to Section 4.7.2 for a description of the wall characteristics. See also Figure 11 .

\subsubsection{Interior-Wall Finish Materials}

The interior walls of Building E5375 are raw or uncoated concrete.

\subsubsection{Piping Attached to or Associated with the Wall}

This elevation of Building E5375 is devoid of interior piping or evidence of piping having been artached to the east interior wall of the building.

\subsubsection{Equipment Connected with this Elevation}

The only equipment located on the east interior wall of the building is a sheet-metal exhaust duct running from the floor of the building through the ceiling (Figure 11). 


\subsubsection{Doors and Windows}

Refer to Section 4.3.3 of this report for a description of the doors and windows in this elevation. See also Figures 6 and 11 .

\subsection{South Interior Elevation}

\subsubsection{Wall Characteristics}

Refer to Section 4.7.2 for a description of the wall characteristics. See also Figure 12.

\subsubsection{Interior-Wall Finish Materials}

The interior walls of Building E5375 are raw or uncoated concrete.

\subsubsection{Piping Attached to or Associated with the Wall}

This elevation of Building E5375 is currently devoid of any interior piping, with the exception of a single piece of disconnected piping over the south entry door. This pipe extends through the roof of the building (Figure 12). Evidence of additional piping once present at this location remains in the form of holes for pipe penetrations through the south exterior wall (Figure 12). Also present in the south elevation is the opening for the pipe trench that connects the building with the railroad siding to the south (Figure 12).

\subsubsection{Equipment Connected with this Elevation}

Refer to Section 4.7.6 for discussion of the equipment associated with this elevation. See also Figures 7, 9, and 12.

\subsubsection{Doors and Windows}

Refer to Section 4.4.3 for a description of the doors and windows present in this elevation. See also Figures 7 and 12. 


\subsection{West Interior Elevation}

\subsubsection{Wall Characteristics}

Refer to Section 4.7.2 for a description of the wall characteristics. See alsn Figure 13.

\subsubsection{Interior-Wall Finish Materials}

The interior walls of Building E5375 are raw or uncoated concrete.

\subsubsection{Piping Attached to or Associated with the Wall}

Located at the west interior wall is the opening for the in-ground pipe trench connecting Buildings E5375 and E5380. This trench contains two 2-in. metal pipes. No other piping is found in this elevation (Figure 13).

\subsubsection{Equipment Connected with this Elevation}

The only equipment located on the west interior wall of the building is some disconnected electrical switching devices and a chart recorder, which is also disconnected (Figure 13).

\subsubsection{Doors and Windows}

Refer to Section 4.5.3 for a description of the doors and windows in this elevation. See also Figures 8 and 13.

\subsection{Ceiling}

\subsubsection{Construction and Condition}

The ceiling of Building E5375 is constructed of Transite panels (Figure 13) There are two large holes in the ceiling remaining from the removal of wind-driven vents that were once mounted on the roof of the building. Currently, rain may enter the building through these holes, which has resulted in an accelerated deterioration of the ceiling and the potential transport of any 
contaminants present via the floor-drain system. Large sections of the ceiling finish are in danger of falling because of the deterioration.

\subsubsection{Piping and Equipment}

There are only two pipes attached to the ceiling of Building E5375. The first of these is the 1 -in. steam line that extends through the window, connecting Building E5375 with the Benzene Tower. A small amount of insulation is still attached to the end of the pipe. The second is a section of disconnected 3-in. piping located over the main entry door. From the fittings on this section of pipe, it is believed that the pipe was part of a steam or compressed-air system (Figure 13). 


\section{Summary of the Geophysics Investigation}

Simultaneously with the building investigation, ANL personnel conducted a geophysical survey of the area directly surrounding Building E5375 (McGinnis et al. 1992). Geophysical measurements were taken using ground penetrating radar (GPR), a horizontal direct-current electrical resistivity (DCER) meter, and a magnetic gradiometer/metal detector. Specific conclusions from this geophysical survey were as follows:

- An underground storage tank (UST) located $25 \mathrm{ft}$ east of Building E5375 is clearly identified with magnetic, resistivity, and GPR profiling. The top of this tank is approximately $1 \mathrm{ft}$ below the ground surface. This is tank number 91606 in APG's UST registry, a 10,000-gal fuel-oil tank installed in 1984.

- A three-point resistivity anomaly, $12 \mathrm{ft}$ east of the northeast corner of Building E5375 and $5 \mathrm{ft}$ south of the area surveyed with the magnetometer, may be caused by a UST. Supporting data from GPR and magnetics are not available for further diagnosis of this anomaly.

- Isolated, one-point magnetic anomalies observed at other APG sites, which are believed to be associated with construction fill, are not seen near Building E5375.

- A 2,500-gamma magnetic anomaly near the northeast corner of the site has no equivalent resistivity anomaly. Disruption in the GPR reflectors was observed, and an object less than $1.5 \mathrm{ft}$ in diameter appears to be buried approximately $2.5 \mathrm{ft}$ below the ground surface. The lack of an electrical anomaly at this location may be due to the small size of the object.

- The source of a magnetic anomaly at the northeast corner of Building E5375 cannot be resolved with available data. The ground surface at this location is undisturbed except for concrete rubble adjacent to the building, which prevents the establishment of a resistivity station. 


\section{Summary and Discussion}

\subsection{Building Operations}

Building E5375 is part of the former CN Production Facility No. 2 at APG. CN was produced at APG by the reaction of chloroacetylchloride (CAC) with benzene in the presence of aluminum chloride (Nemeth 1989). It is believed that benzene was mixed with powdered aluminum chloride, which is insoluble in benzene, in Building E5375 and that the resulting slurry was pumped into the adjacent Building E5380, where the actual $\mathrm{CN}$ production and purification took place. This conclusion is based on the following observations:

1. The size, shape, and configuration of tank No. 3 , which is a relatively small, vertically oriented tank with a conical bottom, is typical of tanks used to handle dry powdered materials, such as aluminum chloride;

2. Tank No. 2 is equipped with agitators, which would be necessary for keeping aluminum chloride in suspension in benzene;

3. The riveted-plate construction of tank No. 2 is typical of a high-pressure tank circa 1940. Steam or compressed air would be applied to this tank to push the benzene/aluminum chloride slurry through the transmission line to Building E5380; and

4. Construction documents for Building E5375 call for tank No. 2 to be installed 3 in. out of level, with the tank outfall being located at the low end (Whitman, Requardt, and Smith Engineers 1941c); this type of installation is often called for when the contents of the tank will be partially solid, as is believed to be the case here.

The exact relation between the two benzene storage tanks is unknown, although tank No. 1 was also equipped with an agitator. Supplemental benzene would have been added from railway tank cars located on the railroad siding south of Building E5375. All material transfer lines originally located within the building have been removed, and the transmission lines to Building E5380 and from the railroad siding have been disconnected at Building E5375.

\subsection{Summary of Potentially Contaminated Compartments}

The compartments listed below represent locations or areas within Building E5375 and the surrounding area that should be considered potentially contaminated. These areas represent the most likely locations for finding contamination at detectable levels. 
1. Concrete floor of the building

2. Contents of both benzene storage tanks

3. Piping leading from railroad siding

4. Piping leading into Building E5380

5. Concrete within both pipe trenches

6. Contents of both floor drains

7. Soil along both of the concrete pipe trenches that are associated with this building

8. Soils from below the floor of the building in the area of the floor drains

9. Contents of the small tank at the elevated entry slab. 


\section{References}

EAI Corporation, 1989, Historical Records Search and Site Survey of Edgewood Area Buildings, Final Report, prepared for U.S. Army Chemical Research, Development, and Engineering Center, Aberdeen Proving Ground, Md., under contract No. DAA15-87-D0021.

McGinnis, M.G., et al., 1992, Interim Progress Report - Geophysics: Building E5375 Decommissioning, Aberdeen Proving Ground, ANL/ESD/TM-37, Argonne National Laboratory, Argonne, Ill.

"National Historic Preservation Act," 1966, Public Law 89-665 (October 15, 1966); "National Historic Preservation Act Amendments," 1980, Public Law 96-515 (December 12, 1980).

Nemeth, G., 1989, RCRA Facility Assessment Report, Edgewood Area, Aberdeen Proving Ground, Maryland, prepared by U.S. Army Environmental Hygiene Agency.

Whitman, Requardt, and Smith Engineers, 1941a, Edgewood Arsenal Benzene Storage Shed Building No. E5375, E5190, Architectural Plans, Elevations, and Section, Microfiche Number 023621, Directorate of Engineering and Housing, Aberdeen Proving Ground, Md. (April 2, 1941).

Whitman, Requardt, and Smith Engineers, 194lb, Edgewood Arsenal Benzene Storage Building No. E5375, E5190, Architectural Plans, Elevations, and Section, Microfiche Number 023667, Directorate of Engineering and Housing, Aberdeen Proving Ground, Md. (March 21, 1941).

Whitman, Requardt, and Smith Engineers, 1941c, Edgewood Arsenal Benzene Storage Building No. E5375, E5190, Concrete Details, Microfiche Number 023786, Directorate of Engineering and Housing, Aberdeen Proving Ground, Md. (April 4, 1941). 


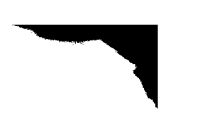
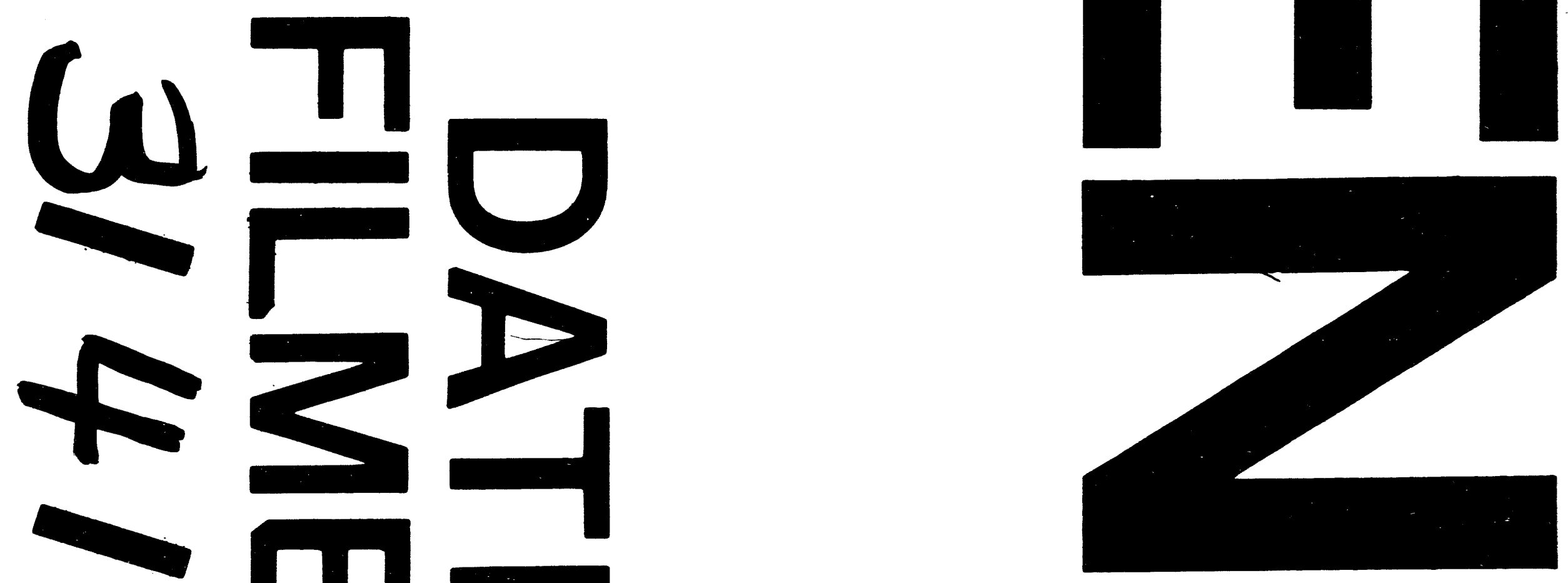
(O)

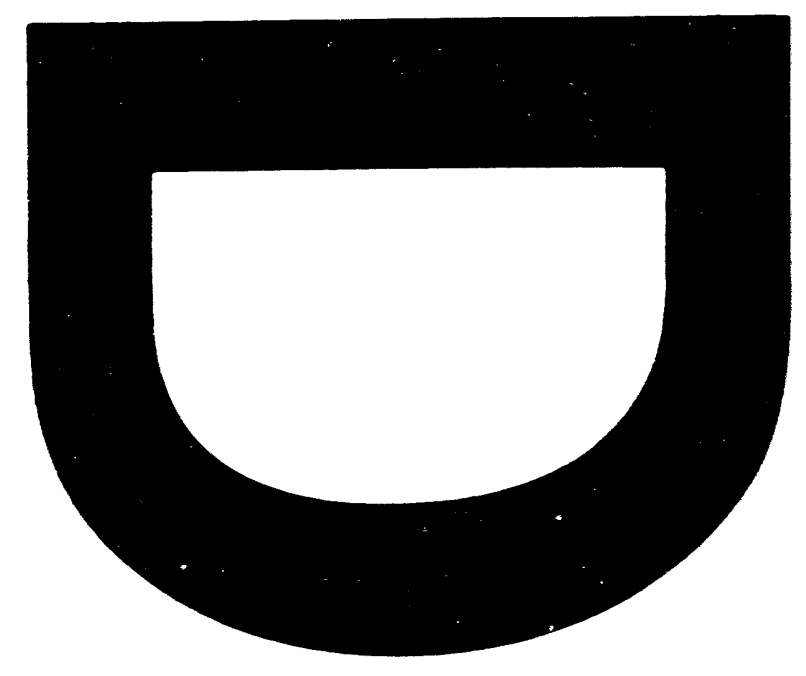


